\title{
Functional analysis of IncRNAs based on competitive endogenous RNA in tongue squamous cell carcinoma
}

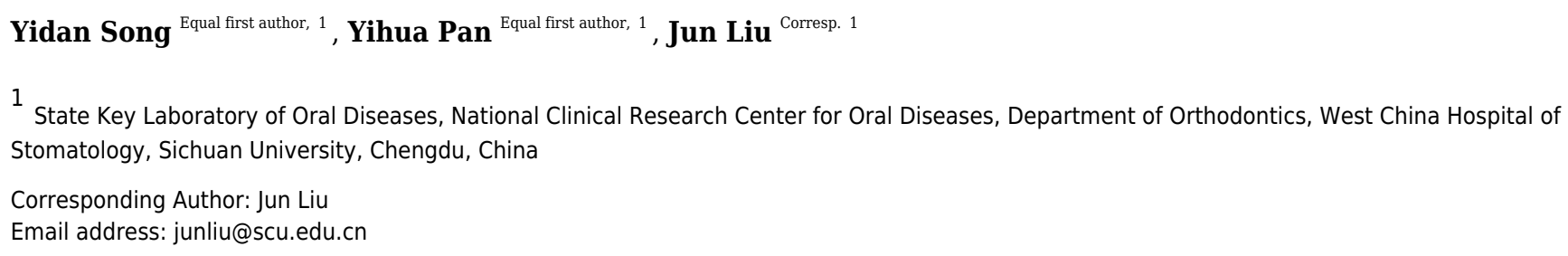

[p] Backround. Tongue

squamous cell carcinoma (TSCC) is the most common malignant tumor in the oral cavity. An increasing number of

studies have suggested that long noncoding RNA (IncRNA) plays an important role in the biological process of

disease and is closely related to the occurrence and development of disease, including TSCC. Although many IncRNAs have been discovered, there remains a lack of research on the function and mechanism of IncRNAs. To better understand the clinical role and biological function of InCRNAs in TSCC, we conducted this study. [p]

[p] Methods. In this study, 162

tongue samples, including 147 TSCC samples and 15

normal control samples, were investigated

and

downloaded from The

Cancer Genome Atlas (TCGA). We constructed a competitive endogenous RNA (ceRNA) regulatory network. Then,

we investigated two IncRNAs as key IncRNAs using Kaplan-Meier curve analysis and constructed a key IncRNA-miRNA-mRNA subnetwork. Furthermore, gene set enrichment analysis ( GSEA ) was carried out on mRNAs in the subnetwork after multivariate survival analysis of the Cox proportional hazards regression model. [p]

Results. The ceRNA regulatory 
network consists of 6

differentially expressed miRNAs (DEmiRNAs), 29 differentially expressed IncRNAs (DEIncRNAs)

and 6 differentially

expressed mRNAs (DEmRNAs). Kaplan-Meier curve analysis of IncRNAs in the TSCC ceRNA regulatory

network showed that only two IncRNAs, including LINC00261 and PART1, are correlated with

the total survival time of TSCC patients. After we constructed the key IncRNA-miRNA -RNA sub network, the GSEA results showed that key IncRNA are mainly related to cytokines and the immune system . High expression levels of LINC00261 indicate a poor prognosis, while a high expression level of PART1 indicates a better prognosis. 
1 Functional analysis of IncRNAs based on competitive endogenous RNA in tongue

2 squamous cell carcinoma

3 Yidan Song1\# Yihua Pan1\# Jun Liu1*

4 \# These authors contributed equally to this work

51 State Key Laboratory of Oral Diseases, National Clinical Research Center for Oral Diseases,

6 Department of Orthodontics, West China Hospital of Stomatology, Sichuan University, Chengdu

7 610041, PR China

*Correspondence to:

Dr. Jun Liu, Associate Professor, State Key Laboratory of Oral Diseases, National Clinical

\title{
For: PeerJ
}

\begin{abstract}
:
Backround. Tongue squamous cell carcinoma (TSCC) is the most common malignant tumor in the oral cavity. An increasing number of studies have suggested that long noncoding RNA (lncRNA) plays an important role in the biological process of disease and is closely related to the occurrence and development of disease, including TSCC. Although many lncRNAs have been discovered, there remains a lack of research on the function and mechanism of lncRNAs. To better understand the clinical role and biological function of lncRNAs in TSCC, we conducted
\end{abstract}


this study.

Methods. In this study, 162 tongue samples, including 147 TSCC samples and 15 normal control samples, were investigated and downloaded from The Cancer Genome Atlas (TCGA). We constructed a competitive endogenous RNA (ceRNA) regulatory network. Then, we investigated two lncRNAs as key lncRNAs using Kaplan-Meier curve analysis and constructed a key lncRNAmiRNA-mRNA subnetwork. Furthermore, gene set enrichment analysis (GSEA) was carried out on mRNAs in the subnetwork after multivariate survival analysis of the Cox proportional hazards regression model.

Results. The ceRNA regulatory network consists of 6 differentially expressed miRNAs (DEmiRNAs), 29 differentially expressed lncRNAs (DElncRNAs) and 6 differentially expressed mRNAs (DEmRNAs). Kaplan-Meier curve analysis of lncRNAs in the TSCC ceRNA regulatory network showed that only two lncRNAs, including LINC00261 and PART1, are correlated with the total survival time of TSCC patients. After we constructed the key lncRNA-miRNA-RNA subnetwork, the GSEA results showed that key lncRNA are mainly related to cytokines and the immune system. High expression levels of LINC00261 indicate a poor prognosis, while a high expression level of PART1 indicates a better prognosis.

\section{Introduction:}

Tongue squamous cell carcinoma (TSCC) is one of the most lethal malignancies of oral cancers, and it is the most common oral cancer ${ }^{1,2}$. TSCC is highly invasive and prone to recurrence and early metastasis, often endangering the lives of patients, and treatment is more difficult. Therefore, exploring the molecular mechanism of the occurrence and development of TSCC, studying the molecular markers of TSCC and finding effective molecular therapeutic targets play an important role in improving the survival rate of patients with TSCC.

In recent years, a regulatory network composed of long noncoding RNAs (lncRNAs), microRNAs (miRNAs) and messenger RNAs (mRNAs) has gained interest in the study of molecular biological mechanisms involved in the process of tumor occurrence and progression. lncRNA is a noncoding RNA with a length greater than 200 nucleotides. Studies have shown that lncRNA plays an important role in many physiological activities, such as the dosage compensation effect, epigenetic regulation, cell cycle regulation and cell differentiation regulation ${ }^{3,4}$. In recent years, increasing evidence has shown that lncRNA has important potential application prospects in the treatment and diagnosis of malignant tumors and other human diseases ${ }^{5,6}$. miRNA is a kind of endogenous small RNA with a length of approximately 20-24 nucleotides that plays a variety of important regulatory roles in cells. miRNA is involved in the regulation of gene expression after transcription in cells. It can act on RNA and render it untranslatable, which leads to the silencing of corresponding genes ${ }^{7}$. Researchers have shown that miRNA is directly related to many important physiological and biochemical processes and diseases, including tumor occurrence and metastasis ${ }^{8,9}$. 
Some RNAs, pseudogenes, long-chain noncoding RNA (lncRNA) and cyclic RNA (circRNA) contain some binding sites for miRNAs, which can competently bind to the same miRNAs through miRNA response elements (MREs), thus eliminating or alleviating the inhibition of miRNAs on target genes and regulating the expression of target genes. This mechanism is referred to as the competitive endogenous RNA (ceRNA) hypothesis ${ }^{10}$. An increasing number of studies have shown that in the process of tumorigenesis, lncRNA can be used as ceRNA, which can inhibit or promote tumorigenesis by competitive binding of the same tumorigenic or antitumorigenic miRNAs ${ }^{11}$. For example, a study showed that lncRNA Gas 5 acts as a ceRNA to regulate PTEN expression by sponging miR-222-3p in papillary thyroid carcinoma ${ }^{12}$. In addition, it has been showed that lncRNA SNHG1 can antagonize the effect of miR-145a-5p on the downregulation of NUAK1 expression in nasopharyngeal carcinoma cells ${ }^{13}$. In order to diagnose and treat oral tumors more accurately, more and more scholars are studying the mechanism of lncRNA in the development of oral tumors. One study explored the role of lncRNA in OSCC by conducting a series of analyses of data downloaded from GEO databases and conducting related experiments to verify the conclusions. Finally, the authors found that lncRNA H1, as a ceRNA, can promote the development of tumors by inhibiting the expression of miR-138 and EZH2, which is helpful for the treatment of OSCC ${ }^{14}$. In addition, some scholars have found that lncRNA OIP5-AS1 is closely related to undifferentiated oral tumors, which can regulate downstream target genes. Moreover, lncRNA OIP5-AS1 can be transactivated by stemness-associated transcription factors in cancer, resulting in poor prognosis ${ }^{15}$. There are an increasing number of studies on the construction of ceRNA networks for cancer research, such as gastric, lung, renal and kidney networks ${ }^{16-19}$. However, until now, there has been nearly no research on lncRNAs and miRNAs related to TSCC based on high-throughput sequencing and a large-scale sample size. The purpose of this study was to analyze the expression of lncRNAs in TSCC and their correlation with clinical indicators based on the competitive endogenous RNA (ceRNA) theory and to explore the possible molecular mechanism of lncRNAs in TSCC by gene set enrichment analysis (GSEA). We aimed to provide new indicators for the early diagnosis and prognosis of TSCC and provide new targets for the treatment of TSCC.

\section{Materials and Methods}

\section{Selection of datasets and data collection}

Gene expression data of TSCC were downloaded from The Cancer Genome Atlas (TCGA) (https://gdc-portal.nci.nih.gov/). TCGA is a project co-supervised by the National Cancer Institute and the National Human Genome Research Institute. It aims to apply high-throughput genome analysis technology to help people have a better understanding of cancer and improve the ability to prevent, diagnose and treat cancer. As the largest cancer gene information database at present, TCGA not only contains many cancer types, but also contains abundant multigroup data. We downloaded RNA-Seq V2 of tongue samples from TCGA, and this data is raw count, which comes from 162 tongue samples. Meanwhile, the downloaded miRNAs-seq came from 169 tongue samples. 
110

111

112

113

114

115

116

117

118

119

120

121

122

123

124

125

126

127

128

129

130

131

132

133

134

135

136

137

138

139

140

141

142

143

144

145

146

147

148

149

\section{RNA sequence data processing}

We downloaded all RNA sequences of 162 tongue samples from TCGA. In addition, we organized the downloaded data into gene expression matrix files and divided the 162 samples into 147 tumor samples and 15 normal control samples by the programming code written in Perl software. And we used the same method to convert the miRNA seq into miRNA matrix files and divided the 169 samples into 154 tumor samples and 15 normal control samples. And we also count the clinical data of the samples. The results are shown in the table 1.

In this study, we mainly used programming code written in Perl software and R language to analyze the RNA data.

\section{Analysis of DEGs, DEIncRNAs, and DEmiRNAs in TSCC}

Ensembl (http://www.ensembl.org/index.html, version 89) ${ }^{20}$ is a software system capable of automatic annotation and maintenance of eukaryotic genomes. It is co-operated by the Wellcome Foundation of Sanger Institute and the European Institute of Bioinformatics, a division of the European Molecular Biology Laboratory. We used the Ensembl database to screen for RNA and lncRNA and exclude the RNA and lncRNA that do not exist in the database.

Before conducting differential expression analysis, we processed the data and deleted outliers samples. Using "WGCNA" package in R software, clustering analysis was carried out on the expression data of mRNA, lncRNA and miRNA respectively, and outlier samples were deleted, the results are shown in supplemental files. Next, we obtained differentially expressed mRNAs (DEmRNAs), lncRNAs (DElncRNAs) and miRNAs (DEmiRNAs) using the "edgeR" package in $\mathrm{R}$ software. The P-value was obtained using the false discovery rate (FDR) to correct the statistical significance of multiple tests. We specified fold changes (log2 absolute) $>2$ and an FDR adjusted to $\mathrm{P}<0.01$ as statistically significant.

\section{Construction of a ceRNA regulatory network}

miRcode database is a software to predict microRNA targets. Currently, it covers a complete set of transcripts annotated by GENCODE, including 10419 registered lncRNAs. When predicting the binding sites of miRNAs, we used the miRNA family defined by Target Scan v6. The miRNAs under the same family have the same binding site type. For the predicted region of the binding sites of miRNAs, the results are filtered and screened according to the gene type, the conservativeness of binding sites and the distribution of transcripts. First, the DElncRNAs and DEmiRNAs were matched in the miRcode database ${ }^{21}$. Unmatched lncRNAs and miRNAs were

deleted. StarBase is used to annotate the suffix of miRNA. miRTarBase ${ }^{22}, \operatorname{miRDB}^{23}$ and TargetScan ${ }^{24}$ databases are all websites that can predict miRNA target genes. In order to make the results more accurate, we used the three databases to predict the target genes of DEmiRNAs. After that, the "Venn Diagram" package in R software was used to screen the target genes of DEmiRNAs by crossing the differentially expressed genes with the target genes, in order to prepare for the construction of ceRNA network. In order to measure the binding, a correlation 
150 analysis is necessary. We used the code in R software to detect the correlation between miRNAs

151

152

153

154

155

156

157

158

159

160

161

162

163

164

165

166

167

168

169

170

171

172

173

174

175

176

177

178

179

180

181

182

183

184

185

186

187

188

189

190

and mRNAs, and between miRNAs and lncRNAs. $\mathrm{P}<0.05$ was considered statistically

significant. The results of correlation analysis were provided in the supplemental files. Then, we obtained the ceRNA regulatory network of lncRNA-miRNA-mRNA and mapped it with Cytoscape software (http://www.cytoscape.org/).

\section{Survival analysis}

We used the "survival" package in R software for survival analysis of all RNAs in the ceRNA network. The expression of lncRNAs, mRNAs and miRNAs correlated with overall survival was identified by the univariate Cox proportional hazards regression model. The expression of RNAs was sequenced from low to high. The first $50 \%$ of the samples were used as the low expression group, and the second $50 \%$ as the high expression group. Then, we used the log-rank test to compare the significant differences in the univariate analysis between subgroups for the overall survival rates. $\mathrm{P}<0.05$ was considered statistically significant.

\section{Construction of the key IncRNA-miRNA-mRNA subnetwork}

We used lncRNAs after survival analysis as key lncRNAs and extracted their linked mRNAs and miRNAs to reconstruct the subnetwork in Cytoscape software.

\section{Multivariate Survival Analysis of Cox Proportional Risk Regression Model}

The Cox proportional hazards regression model plays a key role in the clinical diagnosis of cancer and can be used to detect the risk of key genes. We first downloaded gene expression data from TCGA and then merged the data with Perl script to obtain relevant survival information. Then, mRNAs in the key lncRNA-miRNA-mRNA subnetwork were regarded as key genes. Next, we performed multivariate survival analysis of the key genes using the "survival" package in R software, and the risk level of key genes was obtained. We provided the multi-variate analysis in the supplemental files.

\section{Gene Set Enrichment Analysis (GSEA)}

GSEA connects expression profile chip data with biological significance through statistical analysis, which enables researchers to interpret chip results more easily and reasonably. To further explore the role of the ceRNA regulatory network in the occurrence and development of TSCC, after multivariate analysis, the key genes were divided into two groups according to the risk level as follows: $h$ represents the high gene expression group and 1 represents the low gene expression group. Then, the results were imported into GSEA software. This analysis used two gene sets as follows: the KEGG gene set and the gene ontology gene set, including biological processes, cellular components and molecular functions. FDRs (false discovery rates) $<25 \%$ for the gene sets indicated significantly enriched gene sets using GSEA software. In the GSEA results, the gene set with FDR $<25 \%$ is the enrichment set by default. Because it is possible to generate meaningful hypotheses from these functional genes to facilitate further research. In most cases, the choice of FDR less than $25 \%$ is appropriate.

PeerJ reviewing PDF | (2019:01:34233:2:0:NEW 13 Apr 2019) 
195

196

197

198

199

200

201

202

203

204

205

206

207

208

209

210

211

212

213

214

215

216

217

218

219

220

221

222

223

224

225

226

227

228

229

\section{Data availability}

The datasets analyzed in this study are available in the repository of TCGA (https://portal.gdc.cancer.gov/).

\section{Results}

DERNAs between Primary Tumor and Control Samples

Before the differential expression analysis, the clustering analysis were performed to check the outlier samples. Finally, one cancer sample was deleted from the mRNA data, four control samples were deleted from the lncRNA data, and one control sample was deleted from the miRNA data, the results are shown in supplemental files. Based on the data downloaded from TCGA, using a $\operatorname{logFC}>2$ and an FDR $<0.01$ as the cut-off criterion, we screened 1590 DEmRNAs (Fig.1), including 608 upregulated mRNAs and 982 downregulated mRNAs. Similarly, 627 DElncRNAs (Fig.1) and 75 DEmiRNAs (Fig.1) were obtained, including 401 upregulated and 226 downregulated lncRNAs and 41 upregulated and 34 downregulated miRNAs. Tables 2, 3 and 4 show the first 25 upregulated RNAs and 25 downregulated RNAs and their corresponding $\operatorname{logFC}$ values, P-values, and FDR values. The complete list of DERNAs is provided in supplemental files.

\section{Construction of the ceRNA regulatory network}

To better understand the role of DElncRNAs in TSCC and further elaborate on the interaction between DElncRNAs and DEmiRNAs, a ceRNA regulatory network map related to lncRNAmiRNA-mRNA was constructed using 627 DElncRNAs and 75 DEmiRNAs obtained from the abovementioned studies. In the ceRNA regulatory network of TSCC, the interaction between 627 DEIncRNAs and 75 DERNAs was predicted based on human gene data in the downloaded microcode database using the Perl program. A total of 45 pairs of interacting lncRNAs and microRNAs were obtained. According to the microTarBase, TargetScan and microRNADB databases, 99 DEmiRNAs targeting mRNAs were searched. Then, eight differentially expressed and targeted mRNAs were screened out by comparing the targeted mRNAs with TSCC DEmRNAs from TCGA. Cytoscape was used to construct a ceRNA regulatory network including 6 DEmiRNAs, 29 DElncRNAs and 6 DEmRNAs in TSCC based on the abovementioned RNAs (Fig.2).

\section{Correlation analysis of survival in the ceRNA network}

To further determine whether the expression of genes in the regulatory network is related to the prognosis of TSCC patients, Kaplan-Meier curve analysis of lncRNAs in the TSCC ceRNA regulatory network showed that only two lncRNAs, including LINC00261 and PART1, were correlated with the overall survival time of TSCC patients $(\mathrm{P}<0.05)$, as shown in Figure 3 . Moreover, the expression levels of LINC00261 were negatively correlated with the overall 
230 survival rate, while the expression levels of PART1 were positively correlated with the overall

231 survival rate.

232

233

234

235

236

237

238

239

240

241

242

243

244

245

246

247

248

249

250

251

252

253

254

255

256

257

258

259

260

261

262

263

264

265

266

267

268

269

270

\section{The key IncRNA-miRNA-mRNA sub-network}

LncRNAs and mRNAs appear in the coexpression patterns of ceRNA. Thus, we used two lncRNAs, including LINC00261 and PART1, as the key lncRNAs. We extracted their linked miRNAs and mRNAs and reconstructed a new subnetwork using Cytoscape software. As shown in Figure 4, The lncRNA PART1-miRNA-mRNA subnetwork was composed of 1 lncRNA node, 3 miRNA nodes, and 4 mRNA nodes.

\section{Functional prediction of IncRNAs based on the key IncRNA-miRNA-mRNA subnetwork}

In the network, one or more mRNAs are centered on a lncRNA and connected with it. We can better speculate the function of lncRNA according to the function of the mRNA linked to the lncRNA. Therefore, after multifactor analysis of the mRNAs in the constructed subnetwork, the subnetwork was divided into a high-expression group and a low-expression group according to the risk value, and GSEA analysis was then carried out to explore the biological pathways involved in lncRNA. The GSEA results showed that in the high-expression group of PART1(Fig. 5), six significantly enriched gene sets were screened, including one leukocyte migration gene set, two leukocyte chemotaxis gene sets, one immune system process gene set, one innate immune response gene set and one tyrosine peptide phosphorylation gene set.

\section{Discussion}

In recent decades, TSCC is the most common oral squamous cell carcinoma, and its treatment is difficult. Currently, basic research and clinical treatment of tongue cancer are the focuses of head and neck cancer surgery. The overall clinical treatment of tongue cancer has improved in recent decades. The 5 -year survival rate is $50-60 \%{ }^{25,26}$, but it has been stagnant. Neoadjuvant therapies, such as biotherapy and targeted therapy, have been gradually applied in clinical practice. It has been shown that ceRNAs alter gene expression through a mechanism mediated by microRNAs, thereby affecting cell function, which may lead to cancer ${ }^{10}$. However, only a few studies have been performed on ceRNA in TSCC.

More than 10,000 kinds of lncRNAs have been shown to have potential ceRNA characteristics ${ }^{27}$. In recent years, an increasing number of studies have confirmed that lncRNAs, as a competitive platform for miRNAs and mRNAs, is involved in the regulation of the cell cycle and cell death in various malignant tumors, such as breast, gastric, liver, lung and esophageal cancers ${ }^{28-31}$. LncRNA effects the invasion and metastasis of tumors, thus playing an important role in the occurrence and development of tumors. In the study of TSCC, many lncRNAs have been shown to be associated with the occurrence, development and prognosis of TSCC. In a study published in 2018, a high level of 1ncRNA KCNQ1OT1 expression was shown to be closely correlated with poor prognosis in TSCC. Furthermore, KCNQ1OT1 was shown to promote TSCC 
271 proliferation $^{32}$. Another study showed that lncRNA MALAT1 expression is upregulated in TSCC 272 tissues by investigating the expression and function of MALAT1 in TSCC tissues and cells, and 273 MALAT1 was shown to be related to cervical lymph node metastasis. Finally, MALAT1 was 274 shown to induce cell migration, invasion and EMT and inhibit apoptosis by modulating the 275 Wnt/ $\beta$-catenin signaling pathway ${ }^{33}$. These results may provide new insights for the treatment of 276 TSCC.

277 Therefore, to study the functional roles of lncRNAs as ceRNA in the occurrence and 278 development of TSCC and the regulatory mechanism of lncRNAs, we used data downloaded 279 from TCGA to create a lncRNA-miRNA-mRNA network and carried out a series of analyses, 280 which is very relevant for the treatment of TSCC. In our study, two lncRNAs, including 281 LINC00261 and PART1, were shown to be closely related to overall survival. Patients with high 282 expression levels of LINC00261 had a poor prognosis, while PART1 had the opposite effect. 283 The results of other studies are different from this study. A study ${ }^{34}$ showed that patients with low 284 expression levels of LINC00261 had a higher recurrence rate than those with high expression 285 levels of LINC00261 in gastric cancer, suggesting that patients with low expression levels of 286 LINC00261 have a poor prognosis. We hypothesize that the results are different because of the 287 small number of samples in the present study.

288 Currently, there are few studies on the two kinds of key lncRNAs in TSCC, but many scholars 289 have indicated that these key lncRNAs have an impact on the occurrence and development of 290 other diseases. LINC00261 plays an important role in gastric, lung and colon cancers ${ }^{34-36}$. Many 291 studies have proven that LINC00261 can inhibit cell proliferation and invasion, thus promoting 292 the development of cancer ${ }^{37,38}$. There are fewer studies on PART1 than LNC00261, and only a 293 few studies have investigated its role in prostate cancer and esophageal squamous cell pathway to influence cell proliferation and apoptosis in prostate cancer cells. PART1 can be used as a novel biomarker and target in the treatment of prostate cancer ${ }^{39}$.

The results of enrichment analysis of the lncRNA-miRNA-mRNA subnetwork showed that PART1 is mainly related to cytokines and the immune system and could regulate the immune response and migration of cytokines, thus affecting the occurrence and development of tumors. However, little research has been performed on the effects of these two lncRNAs on immunity and cytokines.

\section{Conclusions:}

Based on the ceRNA theory, we constructed a ceRNA regulatory network, which for the first time enabled an overall perspective and analysis of the lncRNA-associated ceRNA-mediated genes in the development of TSCC at a system-wide level. Our research showed that lncRNAs affect the development of TSCC. Furthermore, the constructed key lncRNA-miRNA-mRNA subnetwork also showed that PART1 can provide new indicators for the early diagnosis and prognosis of TSCC and provide new targets for its treatment. However, the molecular mechanism of the two lncRNAs in TSCC remains unclear. Although the GSEA results provided some research directions, further experiments are needed to verify it. 
312

\section{Acknowledgements:}

314 At the point of finishing this paper, we would like to express our sincere thanks to all those who 315 have lent us hands in the course of our writing this paper. In particular, we would like to thank Dr.

316 Jun Liu for his many suggestions and efforts to improve the research deficiencies. With his help, 317 we accomplished it more smoothly.

\section{Disclosure of interest:}

320 The authors report no conflicts of interest in this work. 
1. Mannelli, G.A., Francesco, Agostini, Tommaso, Innocenti, Marco, Raffaini, Mirco, Spinelli, Giuseppe, Classification of tongue cancer resection and treatment algorithm. Journal of Surgical Oncology, 2018.

2. Kamali, A.G., C. Palmgren, B. Marklund, L. Halle, M. Hammarstedtnordenvall, L, Regional recurrence in early stage I-II oral tongue cancer: a single institutional study and review of the literature. Acta otolaryngologica, 2017. 137(7): p. 1.

3. Peng, W.X., P. Koirala, and Y.Y. Mo, LncRNA-mediated regulation of cell signaling in cancer. Oncogene, 2017. 36(41): p. 5661.

4. Koch, L., Functional genomics: Screening for lncRNA function. Nature Reviews Genetics, 2017. 18(2): p. 70.

5. Fan, J.C.Z., F. Le, Y. G. Xin, L., LncRNA CASC2 inhibited the viability and induced the apoptosis of hepatocellular carcinoma cells through regulating miR-24-3p. Journal of Cellular Biochemistry, 2018. 119(8): p. 6391.

6. Zhang, W.Y., W. Song, J. Wang, S. Gu, X., LncRNA CPS1-IT1 suppresses EMT and metastasis of colorectal cancer by inhibiting hypoxia-induced autophagy through inactivation of HIF-1 $\alpha$. Biochimie, 2018. 144.

7. Wenbin, Y.Q., Lv; Chung-Kwun Amy, Wong; Sean, Hu; Chao, Fu;Zhong, Hua; Guoping, Cai; Guoxi, Li; Yang, Burton B,; Yaou, Zhang, The effect of central loops in miRNA:MRE duplexes on the efficiency of miRNA-mediated gene regulation. Plos One, 2008. 3(3): p. e1719.

8. Wang, C., ., D.Z. Hu, and J.Z. Liu, Identification of critical TF-miRNA-mRNA regulation loops for colorectal cancer metastasis. Genetics \& Molecular Research Gmr, 2016. 14(2): p. 5485-95.

9. Raheleh, A.U., Schmitz;Michael, Linnebacher;Olaf, Wolkenhauer;Ali, Farazmand, MicroRNA-mRNA interactions in colorectal cancer and their role in tumor progression. Genes Chromosomes \& Cancer, 2015. 54(3): p. 129-41.

10. Xiaolong, Q.D.-H., Zhang;Nan, Wu;Jun-Hua, Xiao;Xiang, Wang;Wang, Ma, ceRNA in cancer: possible functions and clinical implications. Journal of Medical Genetics, 2015. 52(10): p. 710-718.

11. Karreth, F.A. and P. Pier Paolo, ceRNA cross-talk in cancer: when ce-bling rivalries go awry. Cancer Discovery, 2013. 3(10): p. 1113-1121.

12. Zhang, X.F., Y. Ye, and S.J. Zhao, LncRNA Gas 5 acts as a ceRNA to regulate PTEN expression by sponging miR-222-3p in papillary thyroid carcinoma. Oncotarget, 2018. 9(3): p. 3519-3530.

13. Lan, X. and X. Liu, LncRNA SNHG1 functions as a ceRNA to antagonize the effect of miR-145a-5p on the down-regulation of NUAK1 in nasopharyngeal carcinoma cell. Journal of Cellular \& Molecular Medicine, 2018.

14. Hong, Y.H., H.;Sui, W.;Zhang, J.;Zhang, S.;Yang, D., Long non-coding RNA H1 promotes cell proliferation and invasion by acting as a ceRNA of miR-138 and releasing EZH2 in oral squamous cell carcinoma. International Journal of Oncology, 2018. 52(3): p. 901-912.

15. Arunkumar, G.A., Shankar;Raksha, Partha;Dhamodharan, Shankar;Subbiah, Shanmugam;Murugan, Avaniyapuram Kannan;Munirajan, Arasambattu Kannan, LncRNAOIP5-AS1is overexpressed in undifferentiated oral tumors and integrated analysis identifies as a downstream effector of stemnessassociated transcription factors. Scientific Reports, 2018. 8(1): p. 7018. 
362 16. Xia, T.L., Q.;Jiang, X.;Shao, Y.;Xiao, B.;Xi, Y.;Guo, J., Long noncoding RNA associated-competing endogenous RNAs in gastric cancer. Sci Rep, 2014. 4: p. 6088.

17. Wang, H.X.D.H.H.C.Y.L.C.Z.C.G.S.Z.L.X.X.X.J., Detection of dysregulated competing endogenous RNA modules associated with clear cell kidney carcinoma. Molecular Medicine Reports, 2018. 18(2): p. 19631972.

18. Qu, L.D., Jin;Chen, Cheng;Wu, Zhen Jie;Liu, Bing;Gao, Yi;Chen, Wei;Liu, Feng;Sun, Wen;Li, Xiao Feng, Exosome-Transmitted IncARSR Promotes Sunitinib Resistance in Renal Cancer by Acting as a Competing Endogenous RNA. Cancer Cell, 2016. 29(5): p. 653-668.

19. Kumar, M.S.A., Elena;East, Philip;Chakravorty, Probir;Matthews, Nik;Winslow, Monte M.;Downward, Julian, Hmga 2 functions as a competing endogenous RNA to promote lung cancer progression. Nature, 2013. 505(7482): p. 212-7.

21. Ashwini, J., D.S. Marks, and L. Erik, miRcode: a map of putative microRNA target sites in the long non-

22. Chih-Hung, C.C., Nai Wen;Sirjana, Shrestha;Sheng-Da, Hsu;Lin, Yu Ling;Wei-Hsiang, Lee;Yang, Chi

29. Zhang, G.L., Shuwei;Lu, Jiafei;Ge, Yuqiu;Wang, Qiaoyan;Ma, Gaoxiang;Zhao, Qinghong;Wu, Dung;Hong, Hsiao Chin;Wei, Ting Yen;Tu, Siang Jyun, miRTarBase 2016: updates to the experimentally validated miRNA-target interactions database. Nucleic Acids Research, 2015. 44(Database issue): p. D239D247.

23. Nathan, W. and W. Xiaowei, miRDB: an online resource for microRNA target prediction and functional annotations. Nucleic Acids Research, 2015. 43(Database issue): p. D146.

24. Fromm, B.B., Tyler;Peck, Liam E.;Johansen, Morten;Tarver, James E.;King, Benjamin L.;Newcomb, James M.;Sempere, Lorenzo F.;Flatmark, Kjersti;Hovig, Eivind, A Uniform System for the Annotation of Vertebrate microRNA Genes and the Evolution of the Human microRNAome. Annual Review of Genetics, 2015. 49(1): p. 213-242.

25. Sano, D. and J.N. Myers, Metastasis of squamous cell carcinoma of the oral tongue. Cancer Metastasis Rev, 2007. 26(3-4): p. 645-662.

26. Torre, L.A.B., F;Siegel, R. L.;Ferlay, J;Lortettieulent, J;Jemal, A, Global cancer statistics, 2012. Ca A Cancer Journal for Clinicians, 2015. 65(2): p. 87-108.

27. Yvonne, T., R. John, and P. Pier Paolo, The multilayered complexity of ceRNA crosstalk and competition. Nature, 2014. 505(7483): p. 344-52.

28. Luan, T.Z., Ximei;Wang, Shuyuan;Song, Yan;Zhou, Shunheng and J.A. ;Lin, Weiwei;Yuan, Weiguang;Yang, Yue;Cai, Huilong, Long non-coding RNA MIAT promotes breast cancer progression and functions as ceRNA to regulate DUSP7 expression by sponging miR-155-5p. Oncotarget, 2017. 8(44): p. 76153-76164. Dongdong;Gong, Weida;Du, Mulong, LncRNA MT1JP functions as a ceRNA in regulating FBXW7 through competitively binding to miR-92a-3p in gastric cancer. Molecular Cancer, 2018. 17(1): p. 87.

0. Wang, H.H., Xisong;Yang, Xin Rong;He, Jia;Cheng, Lijun;Wang, Na;Deng, Xuan;Jin, Haojie;Wang, Ning;Wang, Cun, STAT3-mediated upregulation of IncRNA HOXD-AS1 as a ceRNA facilitates liver cancer 
metastasis by regulating SOX4. Molecular Cancer, 2017. 16(1): p. 136.

31. Jiao, C.S., Z.;Chen, J.;Zhong, J.;Cai, W.;Tian, S.;Chen, S.;Yi, Y.;Xiao, Y., IncRNA-UCA1 enhances cell proliferation through functioning as a ceRNA of Sox4 in esophageal cancer. Oncology Reports, 2016. 36(5): p. 2960.

32. Zhang, S.M., H.;Zhang, D.;Xie, S.;Wang, W.;Li, Q.;Lin, Z.;Wang, Y., LncRNA KCNQ1OT1 regulates proliferation and cisplatin resistance in tongue cancer via miR-211-5p mediated Ezrin/Fak/Src signaling. Cell Death \& Disease, 2018. 9(7): p. 742.

33. Liang, J.L., L.;Ouyang, K.;Li, Z.;Yi, X., MALAT1 induces tongue cancer cells' EMT and inhibits apoptosis through Wnt/B-catenin signaling pathway. Journal of oral pathology \& medicine : official publication of the International Association of Oral Pathologists and the American Academy of Oral Pathology, 2016. 46(2): p. 98.

34. Fan, Y.W., Y. F.;Su, H. F.;Fang, N.;Zou, C.;Li, W. F.;Fei, Z. H., Retraction Note to: Decreased expression of the long noncoding RNA LINC00261 indicate poor prognosis in gastric cancer and suppress gastric cancer metastasis by affecting the epithelial-mesenchymal transition. Journal of Hematology \& Oncology, 2016. 9(1): p. 2.

35. Liu, Y., N. Xiao, and S.F. Xu, Decreased expression of long non-coding RNA LINC00261 is a prognostic marker for patients with non-small cell lung cancer: a preliminary study. European Review for Medical \& Pharmacological Sciences, 2017. 21(24): p. 5691.

36. Wang, Z.K.Y., L;Wu, L. L;Mao, H;Zhou, Y. H;Zhang, P. F;Dai, G.Wang, Z. K;Yang, L;Wu, L. L, Long noncoding RNA LINC00261 sensitizes human colon cancer cells to cisplatin therapy. Brazilian Journal of Medical \& Biological Research, 2018. 51(2): p. e6793.

37. Sha, L.H., Lingxiao;Luo, Xishao;Bao, Jiaping;Gao, Lijun;Pan, Qionghui;Guo, Min;Zheng, Feiyun;Wang, Hanchu, Long non-coding RNA LINC00261 inhibits cell growth and migration in endometriosis. Journal of Obstetrics \& Gynaecology Research, 2017. 43(10): p. 1563.

38. Wang, Y.X., K. Guan, Y. Jin, Y. Liu, S. Wang, Y. Liu, S. Wang, L. Han, L., Long non-coding RNA LINC00261 suppresses cell proliferation and invasion and promotes cell apoptosis in human choriocarcinoma. Oncology Research, 2017. 25(5): p. 733.

39. Sun, M.G., D. Li, S. Chen, Z. Zhao, W., LncRNA PART1 modulates Toll-like receptor pathway to influence cell proliferation and apoptosis in prostate cancer cells. Biological Chemistry, 2017. 399(4).

40. Min, K.R., Meiping. Yan, Li. Fu, Yuqiong. Deng, Minmin.Li, Changping, Exosome-mediated transfer of IncRNA PART1 induces gefitinib resistance in esophageal squamous cell carcinoma via functioning as a competing endogenous RNA. Journal of Experimental \& Clinical Cancer Research, 2018. 37(1): p. 171. 


\section{Figure 1}

\section{Heat maps of DERNAs}

(A) Heat map of DEmRNAs. (B) Heat map of DEIncRNAs. (C) Heat map of DEmiRNAs. The red and green colors indicate higher expression levels and lower expression levels, respectively. The rows represent the DERNAs and the columns represent the samples.

A

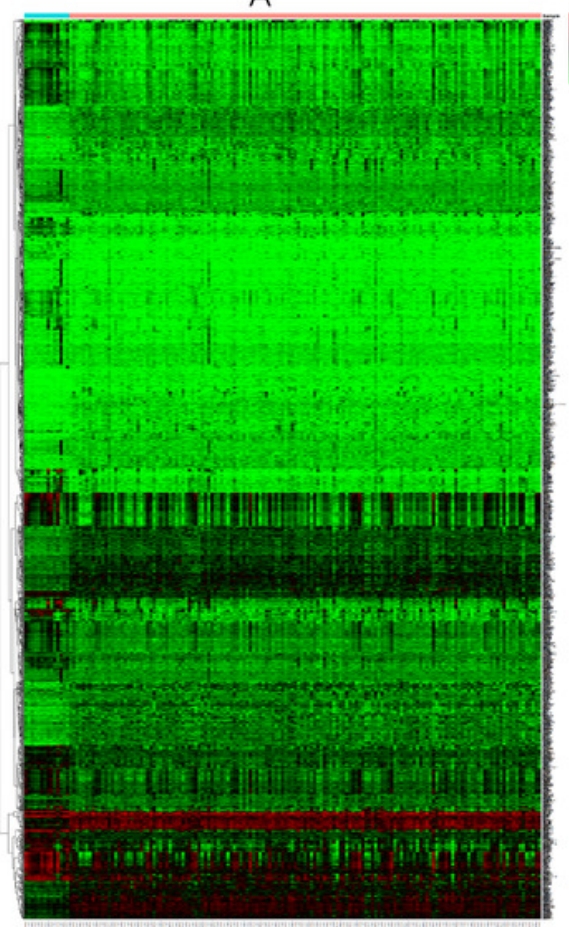

B

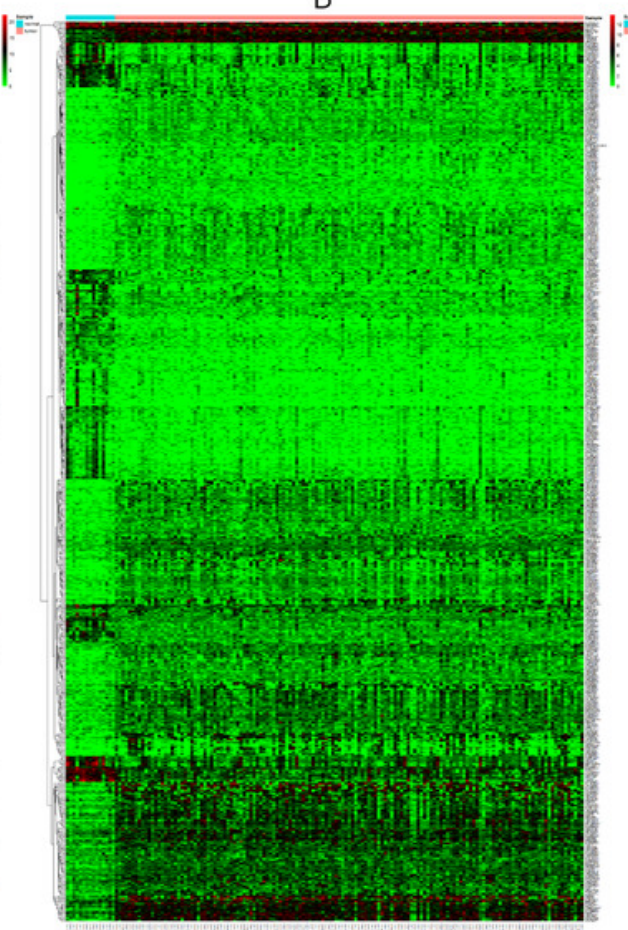

C

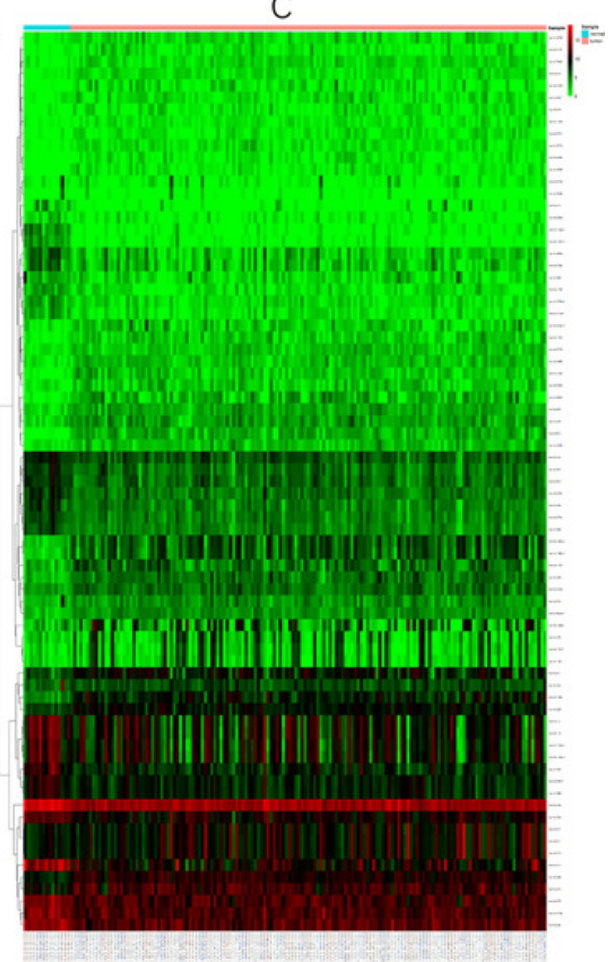




\section{Figure 2}

DEIncRNA - mediated ceRNA regulatory network in tongue squamous cellcarcinoma.

The nodes highlighted in red indicate downregulated expression, and the nodes highlighted in green indicate upregulated expression. IncRNAs, miRNAs and mRNAs are represented by diamonds, rounded rectangles, and ellipses, respectively.

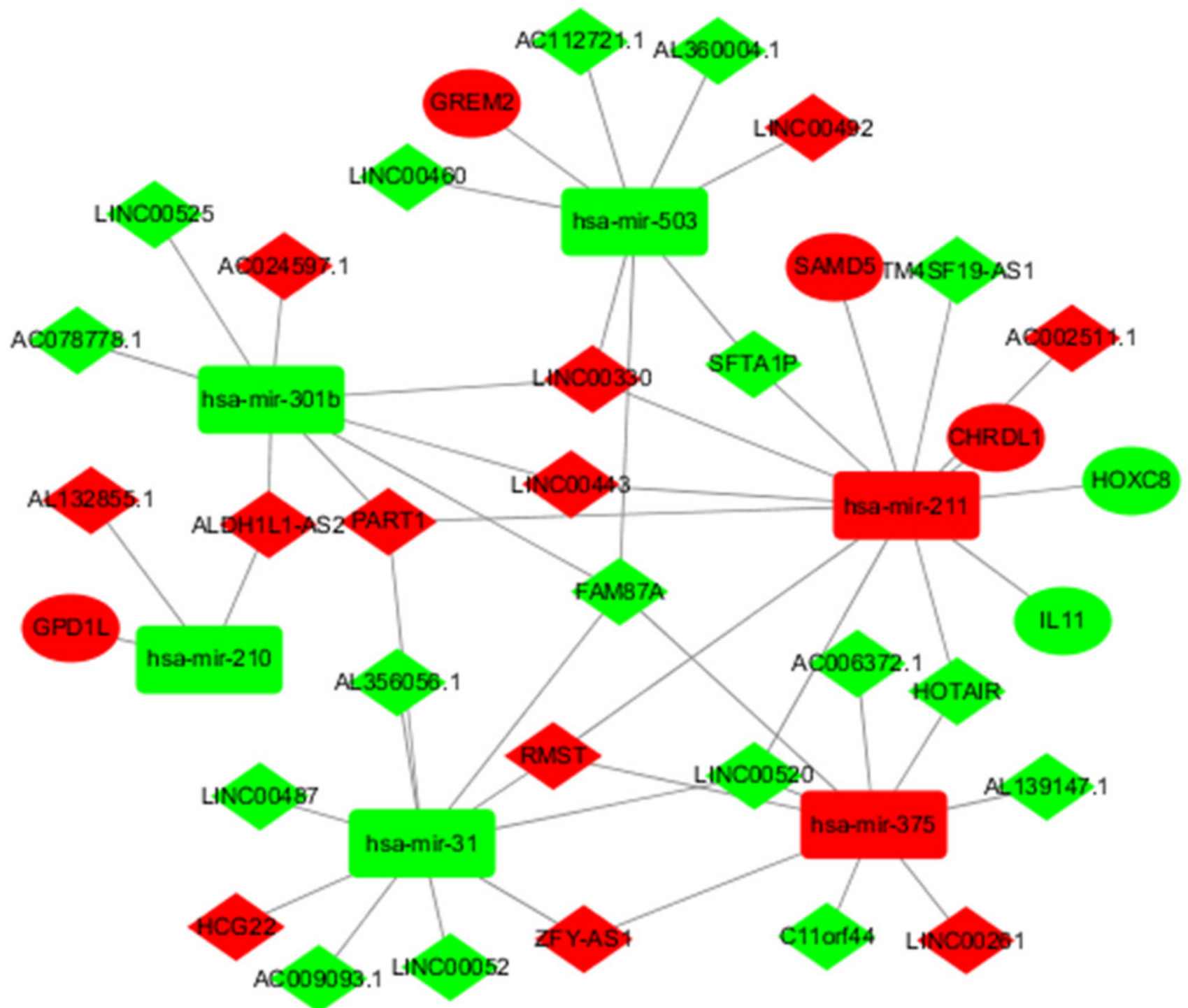


Figure 3

Kaplan-Meiercurve analysis of DEIncRNA ( LINC00261 and PART1) inTSCC patients.

Blue represents low expression and red represents high expression.
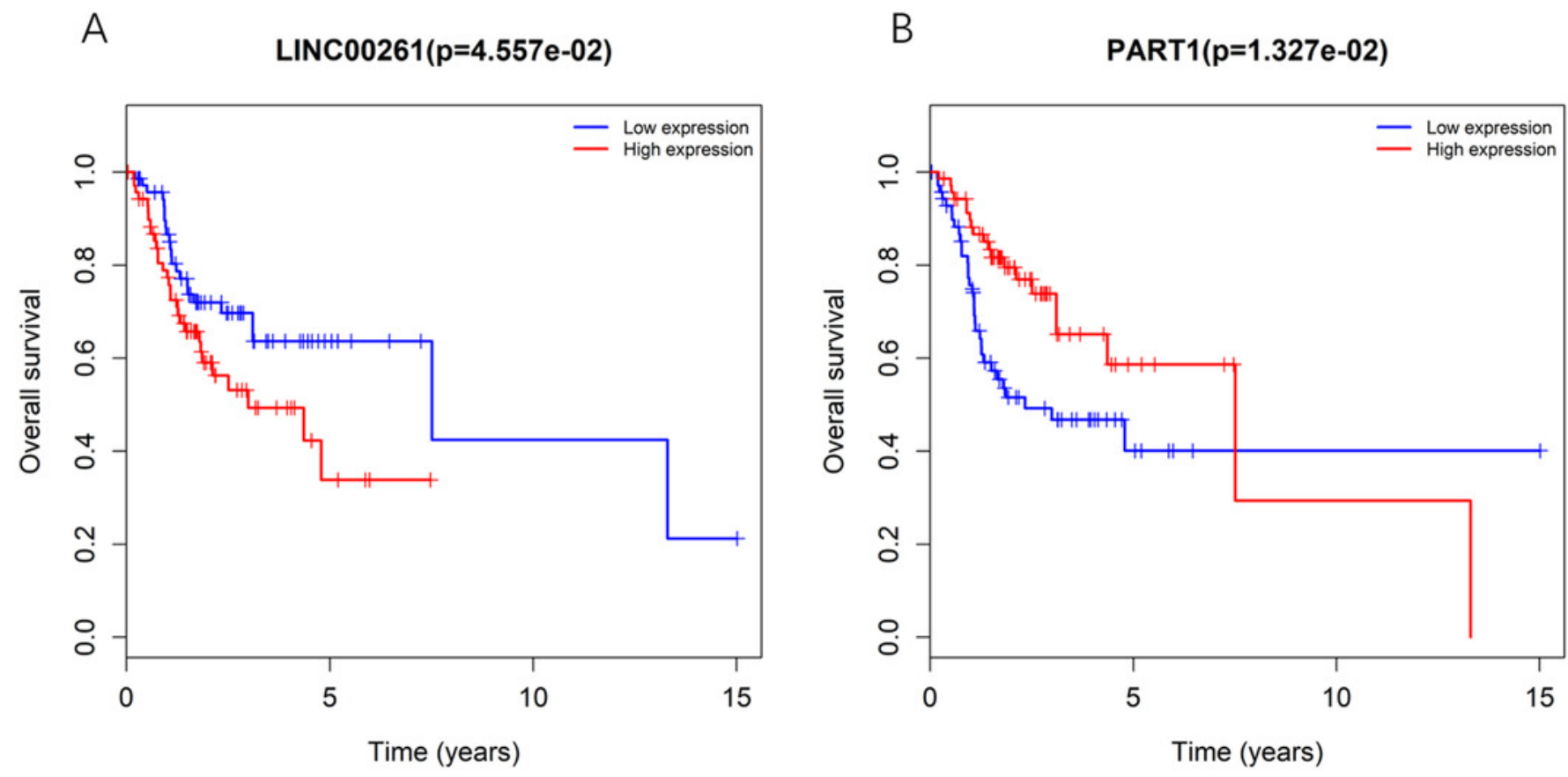


\section{Figure 4}

The subnetwork of PART1.

The nodes highlighted in red indicate downregulated expression, and the nodes highlighted in green indicate upregulated expression. IncRNAs, miRNAs and mRNAs are represented by diamonds, rounded rectangles, and ellipses, respectively.

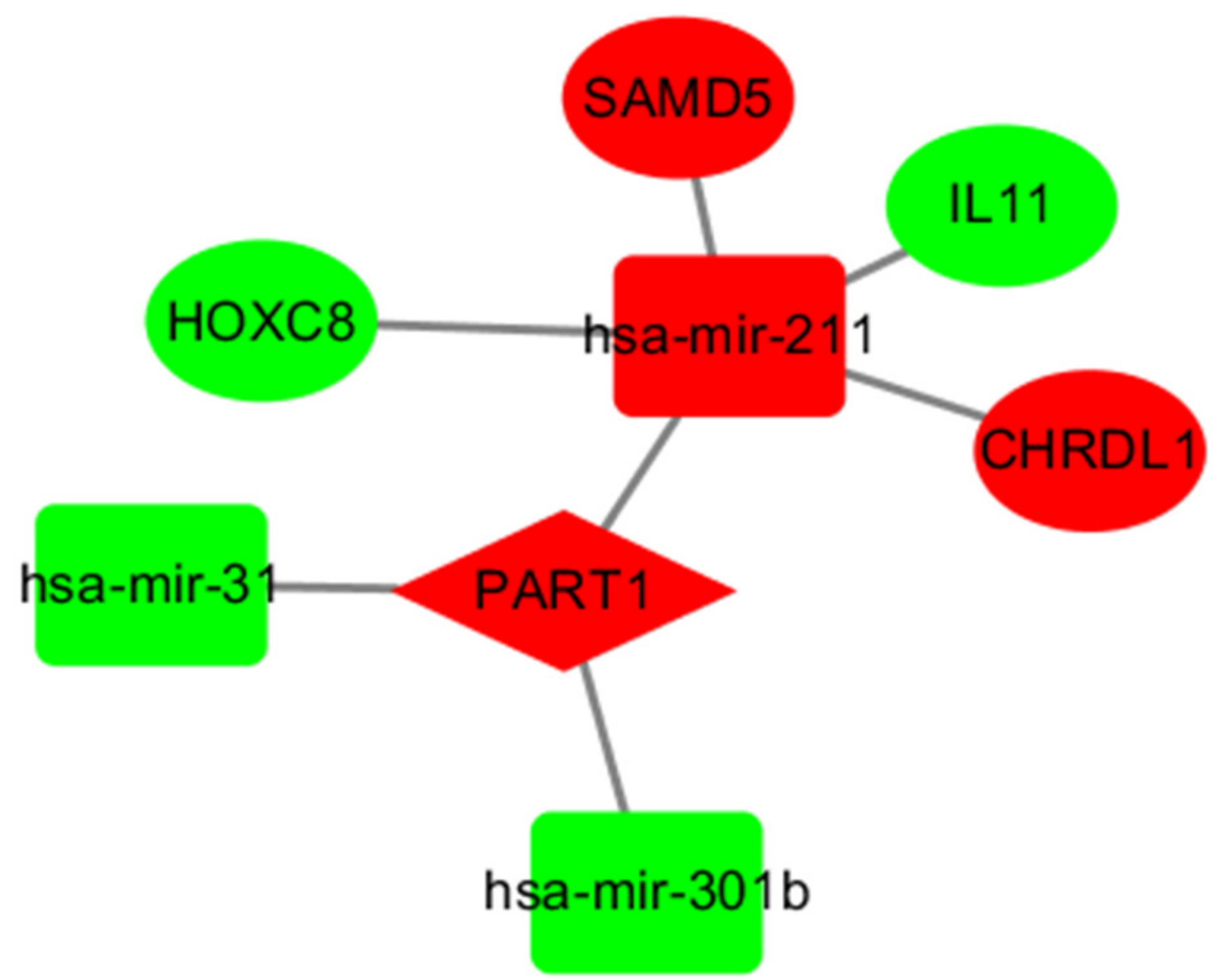




\section{Figure 5}

\section{Gene setenrichment analysis of the subnetwork.}

Gene set enrichment analysis (GSEA) of mRNAs in the subnetwork demonstrated that PART1 is enriched in genes that participate in leukocyte chemotaxis(A), immune system process (B) and peptidyl tyrosine phosphorylation (C).

A

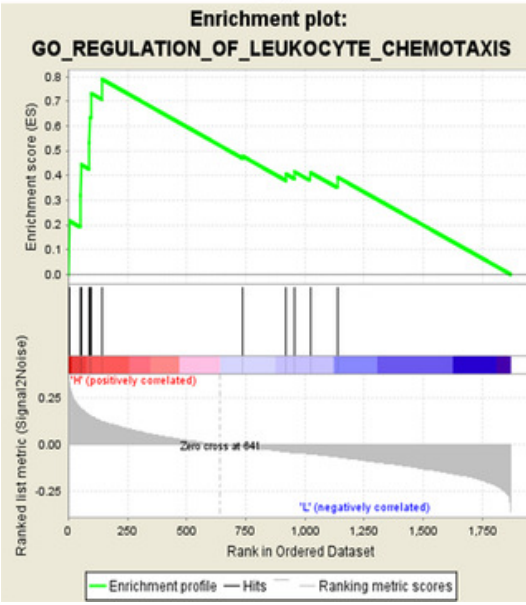

B

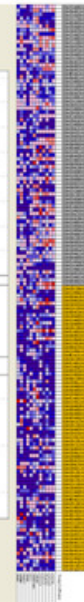

产 0.25 GO_POSITIVE_REGULATION_OF_IMMUNE_SYSTEM_PR OCESS
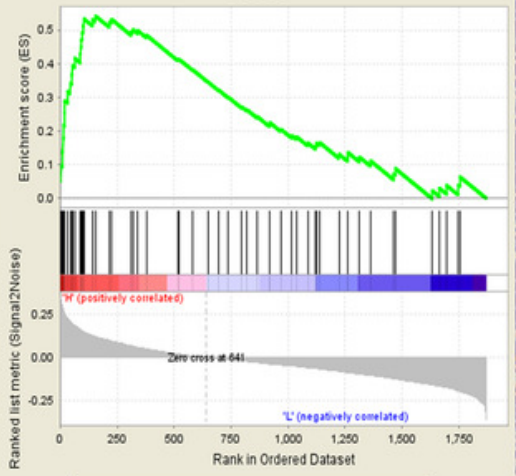

- Enichment profilit - Hiss ${ }^{-}-$Ranking metric scoctess
C

Enrichment plot: GO_REGULATION_OF_PEPTIDYL_TYROSINE_PHOSPHO RYLATION

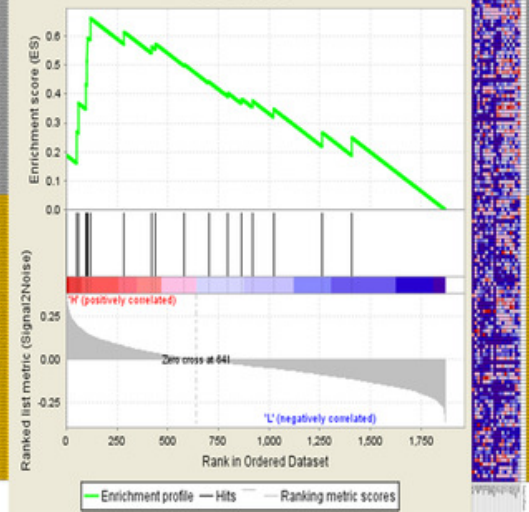




\section{Table $\mathbf{1}$ (on next page)}

Clinical variables in TSCC samples. 


\begin{tabular}{|l|l|l|}
\hline Covariates & Type & Stat \\
\hline fustat & dead & $58(39.5 \%)$ \\
\hline fustat & alive & $89(60.5 \%)$ \\
\hline gender & male & $102(69.4 \%)$ \\
\hline gender & female & $45(30.6 \%)$ \\
\hline age & $<=65$ & $69(46.9 \%)$ \\
\hline age & $>65$ & $78(53.1 \%)$ \\
\hline stage & I & $13(8.8 \%)$ \\
\hline stage & II & $23(15.6 \%)$ \\
\hline stage & III & $32(21.8 \%)$ \\
\hline stage & IV & $73(49.7 \%)$ \\
\hline stage & NA & $6(4.1 \%)$ \\
\hline
\end{tabular}

1 


\section{Table 2 (on next page)}

Top 25 differentiallyexpressed mRNAs in TSCC samples. 


\begin{tabular}{|c|c|c|c|c|c|c|c|c|c|c|c|}
\hline \multicolumn{3}{|c|}{ Top 25 up-regulated mRNAs } & \multirow[b]{2}{*}{$\log \mathrm{CPM}$} & \multirow[b]{2}{*}{ PValue } & \multirow[b]{2}{*}{ FDR } & \multicolumn{3}{|c|}{ Top 25 down-regulated mRNAs } & \multirow[b]{2}{*}{$\log \mathrm{CPM}$} & \multirow[b]{2}{*}{$\begin{array}{l}\text { PValu } \\
\mathrm{e}\end{array}$} & \multirow[b]{2}{*}{ FDR } \\
\hline mRNA & Description & $\log \mathrm{FC}$ & & & & mRNA & Description & $\log \mathrm{FC}$ & & & \\
\hline HOXC8 & homeobox C8 & \begin{tabular}{|l|}
5.28372 \\
7 \\
\end{tabular} & $\begin{array}{l}0.31293 \\
6 \\
\end{array}$ & \begin{tabular}{|l|}
$4.53 \mathrm{E}-$ \\
19 \\
\end{tabular} & $\begin{array}{l}2.79 \mathrm{E}- \\
17 \\
\end{array}$ & PRB3 & $\begin{array}{l}\text { proline rich protein } \\
\text { BstNI subfamily } 3\end{array}$ & $\begin{array}{l}- \\
9.70388 \\
\end{array}$ & \begin{tabular}{|l|}
4.87237 \\
4 \\
\end{tabular} & $\begin{array}{l}7.81 \mathrm{E} \\
-98 \\
\end{array}$ & $\begin{array}{l}1.40 \mathrm{E} \\
-93 \\
\end{array}$ \\
\hline BMP1 & $\begin{array}{l}\text { bone } \\
\text { morphogenetic } \\
\text { protein } 1 \\
\end{array}$ & $\begin{array}{l}2.19807 \\
2\end{array}$ & $\begin{array}{l}6.63863 \\
5\end{array}$ & $\begin{array}{l}3.16 \mathrm{E}- \\
18\end{array}$ & $\begin{array}{l}1.81 \mathrm{E}- \\
16\end{array}$ & PRH1 & $\begin{array}{l}\text { proline rich protein } \\
\text { HaeIII subfamily } 1\end{array}$ & $\begin{array}{l}- \\
7.72276\end{array}$ & $\begin{array}{l}2.56028 \\
8\end{array}$ & $\begin{array}{l}3.04 \mathrm{E} \\
-94\end{array}$ & $\begin{array}{l}2.72 \mathrm{E} \\
-90\end{array}$ \\
\hline MFAP2 & $\begin{array}{l}\text { microfibril } \\
\text { associated } \\
\text { protein } 2 \\
\end{array}$ & $\begin{array}{l}3.18886 \\
1\end{array}$ & $\begin{array}{l}6.04207 \\
1\end{array}$ & $\begin{array}{l}5.08 \mathrm{E}- \\
18\end{array}$ & $\begin{array}{l}2.81 \mathrm{E}- \\
16\end{array}$ & LCN1 & lipocalin 1 & $\begin{array}{l}- \\
11.3997\end{array}$ & $\begin{array}{l}8.08948 \\
3\end{array}$ & $\begin{array}{l}3.38 \mathrm{E} \\
-79\end{array}$ & $\begin{array}{l}2.02 \mathrm{E} \\
-75\end{array}$ \\
\hline PLAU & $\begin{array}{l}\text { plasminogen } \\
\text { activator, } \\
\text { urokinase }\end{array}$ & $\begin{array}{l}3.00587 \\
1\end{array}$ & 8.32712 & $\begin{array}{l}8.47 \mathrm{E}- \\
18\end{array}$ & $\begin{array}{l}4.60 \mathrm{E}- \\
16\end{array}$ & PRR4 & proline rich 4 & $\begin{array}{l}- \\
8.31566\end{array}$ & \begin{tabular}{|l}
5.86588 \\
2
\end{tabular} & $\begin{array}{l}2.35 \mathrm{E} \\
-76\end{array}$ & $\begin{array}{l}1.05 \mathrm{E} \\
-72\end{array}$ \\
\hline C1QTNF6 & $\begin{array}{l}\mathrm{C} 1 \mathrm{q} \text { and } \mathrm{TNF} \\
\text { related } 6\end{array}$ & $\begin{array}{l}3.26488 \\
4\end{array}$ & $\begin{array}{l}5.67327 \\
5\end{array}$ & $\begin{array}{l}4.53 \mathrm{E}- \\
17\end{array}$ & $\begin{array}{l}2.27 \mathrm{E}- \\
15\end{array}$ & OMG & $\begin{array}{l}\text { oligodendrocyte } \\
\text { myelin } \\
\text { glycoprotein } \\
\end{array}$ & -4.8649 & $\begin{array}{l}- \\
0.11353\end{array}$ & $\begin{array}{l}1.75 \mathrm{E} \\
-73\end{array}$ & $\begin{array}{l}6.28 \mathrm{E} \\
-70\end{array}$ \\
\hline $\mathrm{CD} 276$ & CD276 molecule & 2.09334 & $\begin{array}{l}7.16546 \\
3 \\
\end{array}$ & \begin{tabular}{|l|}
$7.14 \mathrm{E}-$ \\
17 \\
\end{tabular} & $\begin{array}{l}.48 \mathrm{E}- \\
15 \\
\end{array}$ & RSPH4A & $\begin{array}{l}\text { radial spoke head } \\
\text { component } 4 \mathrm{~A}\end{array}$ & $\begin{array}{l}- \\
5.17019 \\
\end{array}$ & \begin{tabular}{|l}
0.17947 \\
8 \\
\end{tabular} & $\begin{array}{l}1.19 \mathrm{E} \\
-65 \\
\end{array}$ & $\begin{array}{l}3.57 \mathrm{E} \\
-62 \\
\end{array}$ \\
\hline $\begin{array}{l}\text { SERPINH } \\
1 \\
\end{array}$ & $\begin{array}{l}\text { serpin family } \mathrm{H} \\
\text { member } 1\end{array}$ & \begin{tabular}{|l|}
2.51144 \\
6 \\
\end{tabular} & 8.51167 & \begin{tabular}{|l|}
$7.17 \mathrm{E}-$ \\
17 \\
\end{tabular} & $\begin{array}{l}3.48 \mathrm{E}- \\
15 \\
\end{array}$ & KRT85 & keratin 85 & $\begin{array}{l}- \\
7.19377 \\
\end{array}$ & \begin{tabular}{|l|}
0.58010 \\
9 \\
\end{tabular} & $\begin{array}{l}2.80 \mathrm{E} \\
-62 \\
\end{array}$ & $\begin{array}{l}7.16 \mathrm{E} \\
-59 \\
\end{array}$ \\
\hline COL13A1 & $\begin{array}{l}\text { serpin family } \mathrm{H} \\
\text { member } 1\end{array}$ & \begin{tabular}{|l|}
2.52918 \\
8 \\
\end{tabular} & $\begin{array}{l}2.47466 \\
5 \\
\end{array}$ & \begin{tabular}{|l|}
$1.74 \mathrm{E}-$ \\
16 \\
\end{tabular} & $\begin{array}{l}8.05 \mathrm{E}- \\
15 \\
\end{array}$ & RSPH1 & $\begin{array}{l}\text { radial spoke head } \\
\text { component } 1\end{array}$ & $\begin{array}{l} \\
5.36305 \\
\end{array}$ & \begin{tabular}{|l|}
0.85021 \\
7 \\
\end{tabular} & $\begin{array}{l}1.37 \mathrm{E} \\
-61 \\
\end{array}$ & $\begin{array}{l}3.06 \mathrm{E} \\
-58 \\
\end{array}$ \\
\hline HOXC6 & homeobox C6 & $\begin{array}{l}4.46102 \\
4\end{array}$ & $\begin{array}{l}1.22660 \\
7\end{array}$ & $\begin{array}{l}2.93 \mathrm{E}- \\
16\end{array}$ & $\begin{array}{l}1.34 \mathrm{E}- \\
14\end{array}$ & VWA3B & $\begin{array}{l}\text { von Willebrand } \\
\text { factor A domain } \\
\text { containing } 3 \mathrm{~B} \\
\end{array}$ & $\begin{array}{l}- \\
4.96649\end{array}$ & $\begin{array}{l}0.32137 \\
5\end{array}$ & $\begin{array}{l}1.12 \mathrm{E} \\
-59\end{array}$ & $\begin{array}{l}2.24 \mathrm{E} \\
-56\end{array}$ \\
\hline TGFBI & $\begin{array}{l}\text { transforming } \\
\text { growth factor } \\
\text { beta induced }\end{array}$ & $\begin{array}{l}3.85130 \\
8\end{array}$ & $\begin{array}{l}10.0783 \\
5\end{array}$ & $\begin{array}{l}1.11 \mathrm{E}- \\
15\end{array}$ & $\begin{array}{l}4.78 \mathrm{E}- \\
14\end{array}$ & ZG16B & $\begin{array}{l}\text { zymogen granule } \\
\text { protein } 16 \mathrm{~B}\end{array}$ & $\begin{array}{l}- \\
8.05015\end{array}$ & $\begin{array}{l}7.99639 \\
6\end{array}$ & $\begin{array}{l}1.76 \mathrm{E} \\
-57\end{array}$ & $\begin{array}{l}3.16 \mathrm{E} \\
-54\end{array}$ \\
\hline
\end{tabular}




\begin{tabular}{|c|c|c|c|c|c|c|c|c|c|c|c|}
\hline $\mathrm{HOXC4}$ & homeobox C4 & $\begin{array}{l}3.77763 \\
5\end{array}$ & $\begin{array}{l}1.18955 \\
6\end{array}$ & $\begin{array}{l}1.40 \mathrm{E}- \\
15\end{array}$ & $\begin{array}{l}6.00 \mathrm{E}- \\
14\end{array}$ & C6orf58 & $\begin{array}{l}\text { chromosome } \\
\text { open reading frame } \\
58\end{array}$ & $\begin{array}{l}- \\
8.42169\end{array}$ & 4.31457 & $\begin{array}{l}1.14 \mathrm{E} \\
-56\end{array}$ & $\begin{array}{l}1.86 \mathrm{E} \\
-53\end{array}$ \\
\hline HSD17B6 & $\begin{array}{l}\text { hydroxysteroid } \\
\text { 17-beta } \\
\text { dehydrogenase } 6\end{array}$ & $\begin{array}{l}2.40545 \\
2\end{array}$ & $\begin{array}{l}1.27790 \\
5\end{array}$ & $\begin{array}{l}5.23 \mathrm{E}- \\
15\end{array}$ & $\begin{array}{l}2.07 \mathrm{E}- \\
13\end{array}$ & ZMYND10 & $\begin{array}{l}\text { zinc finger } \\
\text { MYND-type } \\
\text { containing } 10\end{array}$ & -5.1136 & $\begin{array}{l}1.20883 \\
7\end{array}$ & $\begin{array}{l}6.75 \mathrm{E} \\
-54\end{array}$ & $\begin{array}{l}1.01 \mathrm{E} \\
-50\end{array}$ \\
\hline LAMC2 & $\begin{array}{l}\text { laminin subunit } \\
\text { gamma } 2\end{array}$ & $\begin{array}{l}3.83681 \\
5\end{array}$ & $\begin{array}{l}10.6145 \\
6\end{array}$ & $\begin{array}{l}5.85 \mathrm{E}- \\
15\end{array}$ & $\begin{array}{l}2.29 \mathrm{E}- \\
13\end{array}$ & DNAH9 & $\begin{array}{l}\text { dynein axonemal } \\
\text { heavy chain } 9\end{array}$ & $\begin{array}{l}- \\
4.73983\end{array}$ & $\begin{array}{l}1.34368 \\
3\end{array}$ & $\begin{array}{l}2.57 \mathrm{E} \\
-53 \\
\end{array}$ & $\begin{array}{l}3.54 \mathrm{E} \\
-50\end{array}$ \\
\hline GRIN2D & $\begin{array}{l}\text { glutamate } \\
\text { ionotropic } \\
\text { receptor NMDA } \\
\text { type subunit 2D }\end{array}$ & $\begin{array}{l}4.33103 \\
2\end{array}$ & $\begin{array}{l}3.54662 \\
8\end{array}$ & $\begin{array}{l}9.64 \mathrm{E}- \\
15\end{array}$ & $\begin{array}{l}3.69 \mathrm{E}- \\
13\end{array}$ & C9orf24 & $\begin{array}{l}\text { chromosome } 9 \\
\text { open reading frame } \\
24\end{array}$ & $\begin{array}{l}- \\
4.84518\end{array}$ & $\begin{array}{l}- \\
0.09058\end{array}$ & $\begin{array}{l}4.11 \mathrm{E} \\
-53\end{array}$ & $\begin{array}{l}5.26 \mathrm{E} \\
-50\end{array}$ \\
\hline PDPN & podoplanin & $\begin{array}{l}2.69533 \\
3\end{array}$ & 7.36453 & $\begin{array}{l}2.52 \mathrm{E}- \\
14\end{array}$ & $\begin{array}{l}9.09 \mathrm{E}- \\
13\end{array}$ & CFAP43 & $\begin{array}{l}\text { cilia and flagella } \\
\text { associated protein } \\
43\end{array}$ & $\begin{array}{l}- \\
4.37867\end{array}$ & $\begin{array}{l}0.38359 \\
3\end{array}$ & $\begin{array}{l}4.26 \mathrm{E} \\
-52\end{array}$ & $\begin{array}{l}5.09 \mathrm{E} \\
-49\end{array}$ \\
\hline IL11 & interleukin 11 & $\begin{array}{l}3.88134 \\
5\end{array}$ & 3.0041 & $\begin{array}{l}3.16 \mathrm{E}- \\
14 \\
\end{array}$ & $\begin{array}{l}1.12 \mathrm{E}- \\
12\end{array}$ & ECT2L & $\begin{array}{l}\text { epithelial cell } \\
\text { transforming } 2 \text { like }\end{array}$ & $\begin{array}{l}- \\
4.08998 \\
\end{array}$ & $\begin{array}{l}- \\
1.00566 \\
\end{array}$ & $\begin{array}{l}2.97 \mathrm{E} \\
-51 \\
\end{array}$ & $\begin{array}{l}3.33 \mathrm{E} \\
-48 \\
\end{array}$ \\
\hline CA9 & $\begin{array}{l}\text { carbonic } \\
\text { anhydrase } 9\end{array}$ & $\begin{array}{l}5.96295 \\
6 \\
\end{array}$ & $\begin{array}{l}5.02068 \\
2 \\
\end{array}$ & $\begin{array}{l}3.36 \mathrm{E}- \\
14 \\
\end{array}$ & $\begin{array}{l}1.18 \mathrm{E}- \\
12 \\
\end{array}$ & PIFO & $\begin{array}{l}\text { primary cilia } \\
\text { formation }\end{array}$ & $\begin{array}{l}- \\
4.33282 \\
\end{array}$ & $\begin{array}{l}0.83455 \\
3 \\
\end{array}$ & $\begin{array}{l}9.28 \mathrm{E} \\
-51 \\
\end{array}$ & $\begin{array}{l}9.51 \mathrm{E} \\
-48 \\
\end{array}$ \\
\hline P3H1 & $\begin{array}{l}\text { prolyl 3- } \\
\text { hydroxylase } 1\end{array}$ & $\begin{array}{l}2.18219 \\
7\end{array}$ & 5.66245 & $\begin{array}{l}4.70 \mathrm{E}- \\
14\end{array}$ & $\begin{array}{l}1.63 \mathrm{E}- \\
12\end{array}$ & FAM166B & $\begin{array}{l}\text { family with } \\
\text { sequence similarity } \\
166 \text { member B }\end{array}$ & $\begin{array}{l}- \\
3.57818\end{array}$ & $\begin{array}{l}- \\
0.50684\end{array}$ & $\begin{array}{l}9.55 \mathrm{E} \\
-51\end{array}$ & $\begin{array}{l}9.51 \mathrm{E} \\
-48\end{array}$ \\
\hline LBX2 & $\begin{array}{l}\text { ladybird } \\
\text { homeobox } 2\end{array}$ & $\begin{array}{l}2.70721 \\
5\end{array}$ & $\begin{array}{l}- \\
0.43299 \\
\end{array}$ & $\begin{array}{l}1.27 \mathrm{E}- \\
13\end{array}$ & $\begin{array}{l}4.15 \mathrm{E}- \\
12\end{array}$ & LRRC46 & $\begin{array}{l}\text { leucine rich repeat } \\
\text { containing } 46\end{array}$ & $\begin{array}{l}- \\
4.07671\end{array}$ & $\begin{array}{l}0.79616 \\
8\end{array}$ & $\begin{array}{l}7.59 \mathrm{E} \\
-50 \\
\end{array}$ & $\begin{array}{l}7.16 \mathrm{E} \\
-47 \\
\end{array}$ \\
\hline ZNF114 & $\begin{array}{l}\text { zinc finger } \\
\text { protein } 114\end{array}$ & $\begin{array}{l}3.99045 \\
4\end{array}$ & $\begin{array}{l}2.23710 \\
9\end{array}$ & $\begin{array}{l}1.33 \mathrm{E}- \\
13 \\
\end{array}$ & $\begin{array}{l}4.32 \mathrm{E}- \\
12\end{array}$ & TEKT1 & tektin 1 & -5.7258 & $\begin{array}{l}0.09496 \\
7 \\
\end{array}$ & $\begin{array}{l}4.01 \mathrm{E} \\
-49\end{array}$ & $\begin{array}{l}3.59 \mathrm{E} \\
-46\end{array}$ \\
\hline SNX10 & sorting nexin 10 & $\begin{array}{l}2.13915 \\
2 \\
\end{array}$ & $\begin{array}{l}4.01196 \\
7 \\
\end{array}$ & $\begin{array}{l}1.34 \mathrm{E}- \\
13 \\
\end{array}$ & $\begin{array}{l}4.32 \mathrm{E}- \\
12 \\
\end{array}$ & WDR38 & $\begin{array}{l}\text { WD repeat domain } \\
38\end{array}$ & $\begin{array}{l}- \\
5.66533 \\
\end{array}$ & $\begin{array}{l}- \\
0.23915 \\
\end{array}$ & $\begin{array}{l}1.25 \mathrm{E} \\
-48 \\
\end{array}$ & $\begin{array}{l}1.07 \mathrm{E} \\
-45 \\
\end{array}$ \\
\hline DNMT3B & DNA & 2.4099 & 3.44503 & $1.42 \mathrm{E}-$ & $4.57 \mathrm{E}-$ & PRB4 & proline rich protein & - & - & $3.81 \mathrm{E}$ & $3.10 \mathrm{E}$ \\
\hline
\end{tabular}




\begin{tabular}{|c|c|c|c|c|c|c|c|c|c|c|c|}
\hline & $\begin{array}{l}\text { methyltransferas } \\
\text { e } 3 \text { beta }\end{array}$ & & 2 & 13 & 12 & & BstNI subfamily 4 & 9.41497 & 0.08209 & -47 & -44 \\
\hline $\begin{array}{l}\text { TMEM132 } \\
\text { A }\end{array}$ & $\begin{array}{l}\text { transmembrane } \\
\text { protein } 132 \mathrm{~A}\end{array}$ & $\begin{array}{l}2.07118 \\
2\end{array}$ & $\begin{array}{l}7.05342 \\
2\end{array}$ & $\begin{array}{l}1.75 \mathrm{E}- \\
13 \\
\end{array}$ & $\begin{array}{l}5.51 \mathrm{E}- \\
12 \\
\end{array}$ & EFHB & $\begin{array}{l}\text { EF-hand domain } \\
\text { family member B }\end{array}$ & $\begin{array}{l}- \\
4.48575\end{array}$ & $\begin{array}{l}- \\
0.84504\end{array}$ & $\begin{array}{l}5.50 \mathrm{E} \\
-47\end{array}$ & $\begin{array}{l}4.28 \mathrm{E} \\
-44 \\
\end{array}$ \\
\hline HOXC9 & homeobox C9 & $\begin{array}{l}3.90862 \\
3 \\
\end{array}$ & $\begin{array}{l}0.66605 \\
7 \\
\end{array}$ & $\begin{array}{l}2.46 \mathrm{E}- \\
13 \\
\end{array}$ & $\begin{array}{l}7.54 \mathrm{E}- \\
12 \\
\end{array}$ & ERICH3 & glutamate rich 3 & $\begin{array}{l}- \\
6.91452 \\
\end{array}$ & $\begin{array}{l}0.21352 \\
8 \\
\end{array}$ & $\begin{array}{l}1.66 \mathrm{E} \\
-46 \\
\end{array}$ & $\begin{array}{l}1.24 \mathrm{E} \\
-43 \\
\end{array}$ \\
\hline ARTN & artemin & $\begin{array}{l}3.27809 \\
9\end{array}$ & $\begin{array}{l}3.34649 \\
7\end{array}$ & $\begin{array}{l}2.76 \mathrm{E}- \\
13\end{array}$ & $\begin{array}{l}8.34 \mathrm{E}- \\
12\end{array}$ & LPO & lactoperoxidase & $\begin{array}{l}- \\
6.76434\end{array}$ & 1.46561 & $\begin{array}{l}3.06 \mathrm{E} \\
-46\end{array}$ & $\begin{array}{l}2.20 \mathrm{E} \\
-43\end{array}$ \\
\hline
\end{tabular}




\section{Table 3(on next page)}

Top 25 differentiallyexpressed IncRNAs in TSCC samples. 


\begin{tabular}{|c|c|c|c|c|c|c|c|c|c|c|c|}
\hline \multicolumn{2}{|c|}{ Top 25 up-regulated lncRNAs } & \multirow[b]{2}{*}{$\log \mathrm{FC}$} & \multirow[b]{2}{*}{$\log \mathrm{CPM}$} & \multirow[b]{2}{*}{ PValue } & \multirow[b]{2}{*}{ FDR } & \multicolumn{3}{|c|}{ Top 25 down-regulated lncRNAs } & \multirow[b]{2}{*}{$\log \mathrm{CPM}$} & \multirow[b]{2}{*}{ PValue } & \multirow[b]{2}{*}{ FDR } \\
\hline $\operatorname{lncRNA}$ & Description & & & & & $\operatorname{lncRNA}$ & Description & $\log \mathrm{FC}$ & & & \\
\hline LINC02081 & $\begin{array}{l}\text { S-phase cancer } \\
\text { associated } \\
\text { transcript } 1\end{array}$ & 6.55907 & 8.288038 & $\begin{array}{l}1.91 \mathrm{E}- \\
17\end{array}$ & $\begin{array}{l}6.25 \mathrm{E}- \\
15\end{array}$ & LINC01482 & $\begin{array}{l}\text { Long intergenic } \\
\text { non-protein } \\
\text { coding RNA } 1482\end{array}$ & -4.74187 & 5.152461 & $\begin{array}{l}1.46 \mathrm{E}- \\
46\end{array}$ & $\begin{array}{l}1.05 \mathrm{E}- \\
42\end{array}$ \\
\hline HOXC-AS2 & $\begin{array}{l}\text { HOXC cluster } \\
\text { antisense RNA } 2\end{array}$ & 4.769257 & 6.822429 & $\begin{array}{l}1.98 \mathrm{E}- \\
16\end{array}$ & $\begin{array}{l}6.23 \mathrm{E}- \\
14\end{array}$ & LINC01829 & $\begin{array}{l}\text { long intergenic } \\
\text { non-protein } \\
\text { coding RNA } 1829\end{array}$ & -6.36522 & 6.723502 & $\begin{array}{l}3.81 \mathrm{E}- \\
39\end{array}$ & $\begin{array}{l}1.38 \mathrm{E}- \\
35\end{array}$ \\
\hline $\begin{array}{l}\text { ZFPM2- } \\
\text { AS1 }\end{array}$ & $\begin{array}{l}\text { ZFPM2 } \\
\text { antisense RNA } 1\end{array}$ & 6.665231 & 8.995423 & $\begin{array}{l}6.58 \mathrm{E}- \\
16 \\
\end{array}$ & $\begin{array}{l}1.83 \mathrm{E}- \\
13 \\
\end{array}$ & AC027130.1 & Antisense & -5.97661 & 4.460428 & $\begin{array}{l}1.08 \mathrm{E}- \\
36 \\
\end{array}$ & $\begin{array}{l}2.61 \mathrm{E}- \\
33 \\
\end{array}$ \\
\hline GSEC & $\begin{array}{l}\text { G-quadruplex } \\
\text { forming } \\
\text { sequence } \\
\text { containing } \\
\text { lncRNA }\end{array}$ & 3.169551 & 8.755699 & $\begin{array}{l}2.53 \mathrm{E}- \\
15\end{array}$ & $\begin{array}{l}5.70 \mathrm{E}- \\
13\end{array}$ & LINC02160 & $\begin{array}{l}\text { long intergenic } \\
\text { non-protein } \\
\text { coding RNA } 2160\end{array}$ & -6.54927 & 4.019298 & $\begin{array}{l}2.85 \mathrm{E}- \\
35\end{array}$ & $\begin{array}{l}5.15 \mathrm{E}- \\
32\end{array}$ \\
\hline AL358334.2 & novel transcript & 5.390387 & 8.490721 & $\begin{array}{l}3.08 \mathrm{E}- \\
15\end{array}$ & $\begin{array}{l}6.73 \mathrm{E}- \\
13\end{array}$ & RMST & $\begin{array}{l}\text { rhabdomyosarco } \\
\text { ma } 2 \text { associated } \\
\text { transcript }\end{array}$ & -5.26688 & 3.845394 & $\begin{array}{l}2.79 \mathrm{E}- \\
32\end{array}$ & $\begin{array}{l}4.03 \mathrm{E}- \\
29\end{array}$ \\
\hline AC114956.2 & novel transcript & 4.310233 & 8.004771 & $\begin{array}{l}2.70 \mathrm{E}- \\
14\end{array}$ & $\begin{array}{l}5.13 \mathrm{E}- \\
12\end{array}$ & AC010425.1 & novel transcript & -5.48585 & 3.476603 & $\begin{array}{l}1.74 \mathrm{E}- \\
26\end{array}$ & $\begin{array}{l}2.10 \mathrm{E}- \\
23\end{array}$ \\
\hline $\begin{array}{l}\text { FOXD2- } \\
\text { AS1 }\end{array}$ & $\begin{array}{ll}\text { adjacent } & \\
\text { opposite strand } \\
\text { RNA 1 }\end{array}$ & 2.583099 & 8.660159 & $\begin{array}{l}1.58 \mathrm{E}- \\
13\end{array}$ & $\begin{array}{l}2.60 \mathrm{E}- \\
11\end{array}$ & LINC01798 & $\begin{array}{l}\text { long intergenic } \\
\text { non-protein } \\
\text { coding RNA } 1798\end{array}$ & -3.58562 & 4.324626 & $\begin{array}{l}8.21 \mathrm{E}- \\
26\end{array}$ & $\begin{array}{l}8.46 \mathrm{E}- \\
23\end{array}$ \\
\hline AC114956.1 & novel transcript & 4.215066 & 6.515797 & $\begin{array}{l}5.15 \mathrm{E}- \\
13\end{array}$ & $\begin{array}{l}7.91 \mathrm{E}- \\
11\end{array}$ & LINC01797 & $\begin{array}{l}\text { long intergenic } \\
\text { non-protein } \\
\text { coding RNA } 1797\end{array}$ & -6.20978 & 3.390637 & $\begin{array}{l}1.23 \mathrm{E}- \\
24\end{array}$ & $\begin{array}{l}1.11 \mathrm{E}- \\
21\end{array}$ \\
\hline $\begin{array}{l}\text { HOXA10- } \\
\text { AS }\end{array}$ & $\begin{array}{l}\text { HOXA10 } \\
\text { antisense RNA }\end{array}$ & 5.742475 & 5.845017 & $\begin{array}{l}1.66 \mathrm{E}- \\
12\end{array}$ & $\begin{array}{l}2.36 \mathrm{E}- \\
10\end{array}$ & FOXCUT & $\begin{array}{l}\text { FOXC1 upstream } \\
\text { transcript }\end{array}$ & -4.07718 & 5.643834 & $\begin{array}{l}6.56 \mathrm{E}- \\
24\end{array}$ & $\begin{array}{l}5.26 \mathrm{E}- \\
21\end{array}$ \\
\hline
\end{tabular}




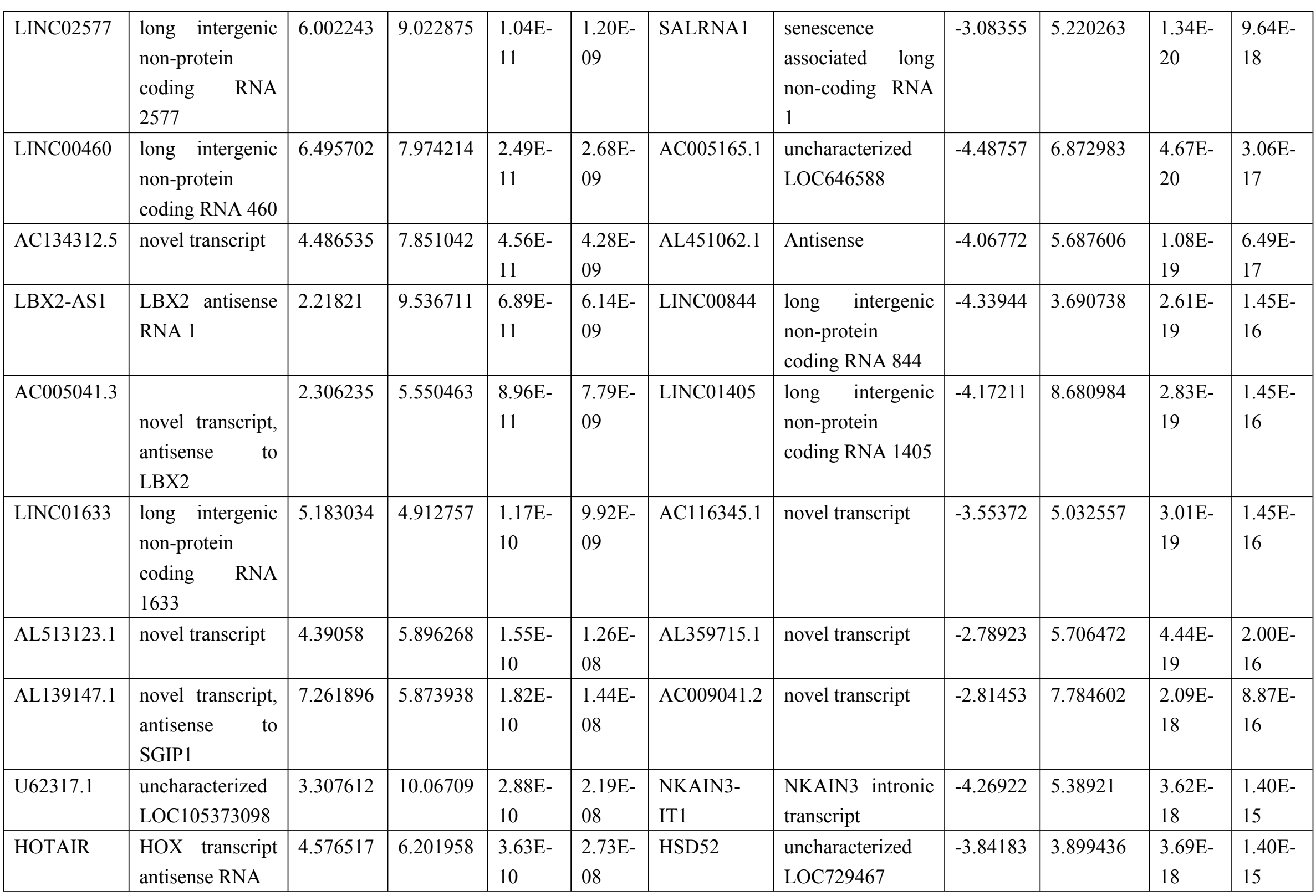




\begin{tabular}{|c|c|c|c|c|c|c|c|c|c|c|c|}
\hline LINC01615 & $\begin{array}{l}\text { long intergenic } \\
\text { non-protein } \\
\text { coding RNA } \\
1615\end{array}$ & 4.411259 & 9.631277 & $\begin{array}{l}4.36 \mathrm{E}- \\
10\end{array}$ & $\begin{array}{l}3.21 \mathrm{E}- \\
08\end{array}$ & LINC02343 & $\begin{array}{l}\text { long intergenic } \\
\text { non-protein } \\
\text { coding RNA } 2343\end{array}$ & -5.54729 & 3.466708 & $\begin{array}{l}6.86 \mathrm{E}- \\
18\end{array}$ & $\begin{array}{l}2.48 \mathrm{E}- \\
15\end{array}$ \\
\hline $\begin{array}{l}\text { SLC12A5- } \\
\text { AS1 }\end{array}$ & $\begin{array}{l}\text { SLC12A5 and } \\
\text { MMP9 antisense } \\
\text { RNA } 1\end{array}$ & 3.954435 & 6.183039 & $\begin{array}{l}4.91 \mathrm{E}- \\
10\end{array}$ & $\begin{array}{l}3.54 \mathrm{E}- \\
08\end{array}$ & AL161668.4 & novel transcript & -3.7574 & 4.738385 & $\begin{array}{l}7.66 \mathrm{E}- \\
18\end{array}$ & $\begin{array}{l}2.63 \mathrm{E}- \\
15\end{array}$ \\
\hline AC113346.1 & novel transcript & 5.684313 & 5.792491 & $\begin{array}{l}5.03 \mathrm{E}- \\
10 \\
\end{array}$ & $\begin{array}{l}3.60 \mathrm{E}- \\
08\end{array}$ & SOX9-AS1 & $\begin{array}{ll}\text { SOX9 } & \text { antisense } \\
\text { RNA } 1 & \end{array}$ & -2.54064 & 7.026463 & $\begin{array}{l}2.56 \mathrm{E}- \\
16 \\
\end{array}$ & $\begin{array}{l}7.70 \mathrm{E}- \\
14\end{array}$ \\
\hline LINC00941 & $\begin{array}{l}\text { long intergenic } \\
\text { non-protein } \\
\text { coding RNA } 941 \\
\end{array}$ & 4.33015 & 8.913483 & $\begin{array}{l}5.20 \mathrm{E}- \\
10\end{array}$ & $\begin{array}{l}3.68 \mathrm{E}- \\
08\end{array}$ & $\begin{array}{l}\text { ZNF710- } \\
\text { AS1 }\end{array}$ & $\begin{array}{l}\text { ZNF710 antisense } \\
\text { RNA } 1\end{array}$ & -2.32401 & 9.970743 & $\begin{array}{l}6.09 \mathrm{E}- \\
16\end{array}$ & $\begin{array}{l}1.76 \mathrm{E}- \\
13\end{array}$ \\
\hline $\begin{array}{l}\text { RNF144A- } \\
\text { AS1 }\end{array}$ & $\begin{array}{l}\text { RNF144A } \\
\text { antisense RNA } 1\end{array}$ & 3.391581 & 7.876758 & $\begin{array}{l}7.03 \mathrm{E}- \\
10\end{array}$ & $\begin{array}{l}4.83 \mathrm{E}- \\
08\end{array}$ & DRAIC & \begin{tabular}{l}
\multicolumn{2}{l}{ downregulated } \\
RNA in cancer, \\
inhibitor of cell \\
invasion \\
migration
\end{tabular} & -2.84397 & 5.017242 & $\begin{array}{l}7.74 \mathrm{E}- \\
16\end{array}$ & $\begin{array}{l}2.07 \mathrm{E}- \\
13\end{array}$ \\
\hline LINC01614 & $\begin{array}{l}\text { long intergenic } \\
\text { non-protein } \\
\text { coding RNA } \\
1614\end{array}$ & 7.771486 & 8.166619 & $\begin{array}{l}1.24 \mathrm{E}- \\
09\end{array}$ & $\begin{array}{l}8.26 \mathrm{E}- \\
08\end{array}$ & AC002401.3 & $\begin{array}{l}\text { novel transcript, } \\
\text { antisense to PDK2 }\end{array}$ & -3.1933 & 3.763892 & $\begin{array}{l}1.10 \mathrm{E}- \\
15\end{array}$ & $\begin{array}{l}2.84 \mathrm{E}- \\
13\end{array}$ \\
\hline
\end{tabular}




\section{Table 4(on next page)}

Top 25 differentially expressed miRNAs in TSCCsamples. 


\begin{tabular}{|c|c|c|c|c|c|c|c|c|c|}
\hline \multicolumn{3}{|c|}{ Top 25 up-regulated miRNAs } & \multirow[b]{2}{*}{ PValue } & \multirow[b]{2}{*}{ FDR } & \multicolumn{3}{|c|}{ Top 25 down-regulated miRNAs } & \multirow[b]{2}{*}{ PValue } & \multirow[b]{2}{*}{ FDR } \\
\hline miRNA & $\operatorname{logFC}$ & $\log \mathrm{CPM}$ & & & miRNA & $\operatorname{logFC}$ & $\log \mathrm{CPM}$ & & \\
\hline hsa-mir-615 & 5.730799 & 1.478439 & $6.70 \mathrm{E}-17$ & $2.22 \mathrm{E}-15$ & hsa-mir-299 & $\begin{array}{l}- \\
2.99771\end{array}$ & 3.863924 & $\begin{array}{l}1.11 \mathrm{E}- \\
32\end{array}$ & $6.98 \mathrm{E}-30$ \\
\hline hsa-mir-455 & 2.538941 & 8.844984 & $5.06 \mathrm{E}-15$ & $1.38 \mathrm{E}-13$ & hsa-mir-135a-2 & $\begin{array}{l}- \\
5.11378\end{array}$ & 0.187823 & $\begin{array}{l}3.80 \mathrm{E}- \\
32\end{array}$ & $1.19 \mathrm{E}-29$ \\
\hline hsa-mir-196b & 4.394713 & 7.097162 & $1.72 \mathrm{E}-13$ & $3.72 \mathrm{E}-12$ & hsa-mir-381 & $\begin{array}{l}- \\
3.59226\end{array}$ & 7.848088 & $\begin{array}{l}4.55 \mathrm{E}- \\
31\end{array}$ & $9.53 \mathrm{E}-29$ \\
\hline hsa-mir-196a-2 & 4.970325 & 5.132245 & $2.79 \mathrm{E}-12$ & $5.17 \mathrm{E}-11$ & hsa-mir-135a-1 & $\begin{array}{l}- \\
4.56572\end{array}$ & -0.16831 & $\begin{array}{l}1.59 \mathrm{E}- \\
28\end{array}$ & $2.51 \mathrm{E}-26$ \\
\hline hsa-mir-503 & 3.184672 & 3.776945 & $1.55 \mathrm{E}-11$ & $2.57 \mathrm{E}-10$ & hsa-mir-30a & $\begin{array}{l}- \\
2.10026 \\
\end{array}$ & 13.63923 & $\begin{array}{l}3.18 \mathrm{E}- \\
23 \\
\end{array}$ & $4.01 \mathrm{E}-21$ \\
\hline hsa-mir-196a-1 & 4.906809 & 4.980926 & $1.94 \mathrm{E}-11$ & $2.97 \mathrm{E}-10$ & hsa-mir-885 & $\begin{array}{l}- \\
4.10373\end{array}$ & 1.650439 & $\begin{array}{l}4.81 \mathrm{E}- \\
22\end{array}$ & $5.04 \mathrm{E}-20$ \\
\hline hsa-mir-224 & 2.141737 & 7.121961 & $9.49 \mathrm{E}-10$ & $1.15 \mathrm{E}-08$ & hsa-mir-378c & $\begin{array}{l} \\
2.49589\end{array}$ & 4.056665 & $\begin{array}{l}9.94 \mathrm{E}- \\
22\end{array}$ & $8.93 \mathrm{E}-20$ \\
\hline hsa-mir-450a-1 & 2.045314 & 2.394319 & $1.39 \mathrm{E}-09$ & $1.62 \mathrm{E}-08$ & hsa-mir-411 & $\begin{array}{l}- \\
2.72564 \\
\end{array}$ & 4.401595 & $\begin{array}{l}1.26 \mathrm{E}- \\
21 \\
\end{array}$ & $9.90 \mathrm{E}-20$ \\
\hline hsa-mir-877 & 2.435612 & 1.584991 & 2.04E-09 & $2.33 \mathrm{E}-08$ & hsa-mir-34c & $\begin{array}{l}- \\
2.75873 \\
\end{array}$ & 5.722292 & $\begin{array}{l}3.57 \mathrm{E}- \\
21\end{array}$ & $2.50 \mathrm{E}-19$ \\
\hline hsa-mir-1910 & 3.99605 & 0.658871 & $2.55 \mathrm{E}-09$ & $2.82 \mathrm{E}-08$ & hsa-mir-375 & $\begin{array}{l}- \\
3.96099\end{array}$ & 11.45332 & $\begin{array}{l}2.19 \mathrm{E}- \\
19\end{array}$ & $1.15 \mathrm{E}-17$ \\
\hline hsa-mir-301a & 2.09408 & 3.746788 & $3.37 \mathrm{E}-08$ & $3.17 \mathrm{E}-07$ & hsa-mir-378a & $\begin{array}{l}- \\
2.24997\end{array}$ & 10.81757 & $\begin{array}{l}6.76 \mathrm{E}- \\
19\end{array}$ & $3.04 \mathrm{E}-17$ \\
\hline hsa-mir-4652 & 4.667714 & 1.65468 & $6.24 \mathrm{E}-08$ & $5.45 \mathrm{E}-07$ & hsa-mir-376c & $\begin{array}{l}- \\
2.27353\end{array}$ & 3.501245 & $\begin{array}{l}1.03 \mathrm{E}- \\
18\end{array}$ & $4.31 \mathrm{E}-17$ \\
\hline hsa-mir-1305 & 3.364084 & 0.561589 & $1.34 \mathrm{E}-07$ & $1.11 \mathrm{E}-06$ & hsa-mir-495 & $\begin{array}{l}- \\
2.18082\end{array}$ & 3.324704 & $\begin{array}{l}3.04 \mathrm{E}- \\
18\end{array}$ & $1.19 \mathrm{E}-16$ \\
\hline hsa-mir-210 & 2.331449 & 10.02408 & $3.90 \mathrm{E}-07$ & $2.89 \mathrm{E}-06$ & hsa-mir-486-2 & - & 7.190098 & 9.14E- & $3.35 \mathrm{E}-16$ \\
\hline
\end{tabular}




\begin{tabular}{|c|c|c|c|c|c|c|c|c|c|}
\hline & & & & & & 2.33925 & & 18 & \\
\hline hsa-mir-7705 & 2.102799 & 0.65585 & $6.32 \mathrm{E}-07$ & $4.51 \mathrm{E}-06$ & hsa-mir-486-1 & $\begin{array}{l}- \\
2.35431\end{array}$ & 7.205133 & $\begin{array}{l}9.59 \mathrm{E}- \\
18\end{array}$ & $3.35 \mathrm{E}-16$ \\
\hline hsa-mir-937 & 2.549417 & 2.138107 & $8.21 \mathrm{E}-07$ & $5.80 \mathrm{E}-06$ & hsa-mir-29c & $\begin{array}{l}- \\
2.08372 \\
\end{array}$ & 11.16676 & $\begin{array}{l}1.91 \mathrm{E}- \\
16 \\
\end{array}$ & $6.01 \mathrm{E}-15$ \\
\hline hsa-mir-7854 & 2.596544 & -0.02223 & $1.05 \mathrm{E}-06$ & $7.28 \mathrm{E}-06$ & hsa-mir-378d-2 & $\begin{array}{l}- \\
2.58036\end{array}$ & 0.400949 & $\begin{array}{l}2.85 \mathrm{E}- \\
16 \\
\end{array}$ & $8.52 \mathrm{E}-15$ \\
\hline hsa-mir-3940 & 2.188397 & 0.789722 & $1.10 \mathrm{E}-06$ & $7.53 \mathrm{E}-06$ & hsa-mir-34b & $\begin{array}{l}- \\
2.52533 \\
\end{array}$ & 3.09759 & $\begin{array}{l}3.37 \mathrm{E}- \\
15 \\
\end{array}$ & $9.63 \mathrm{E}-14$ \\
\hline hsa-mir-301b & 2.409846 & 1.003252 & $1.36 \mathrm{E}-06$ & $9.09 \mathrm{E}-06$ & hsa-mir-337 & $\begin{array}{l}- \\
2.10921\end{array}$ & 5.058 & $\begin{array}{l}9.56 \mathrm{E}- \\
15\end{array}$ & $2.51 \mathrm{E}-13$ \\
\hline hsa-mir-545 & 2.274835 & -0.21026 & $1.89 \mathrm{E}-06$ & $1.22 \mathrm{E}-05$ & hsa-mir-379 & $\begin{array}{l}- \\
2.01836\end{array}$ & 10.57229 & $\begin{array}{l}1.61 \mathrm{E}- \\
14\end{array}$ & $4.06 \mathrm{E}-13$ \\
\hline hsa-mir-1293 & 3.020534 & 4.296348 & $2.21 \mathrm{E}-06$ & $1.39 \mathrm{E}-05$ & hsa-mir-1258 & -2.5535 & 0.159542 & $\begin{array}{l}2.30 \mathrm{E}- \\
14\end{array}$ & $5.57 \mathrm{E}-13$ \\
\hline hsa-mir-31 & 2.620164 & 7.436808 & $3.09 \mathrm{E}-06$ & $1.85 \mathrm{E}-05$ & hsa-mir-410 & $\begin{array}{l} \\
2.26437\end{array}$ & 4.466849 & $\begin{array}{l}3.02 \mathrm{E}- \\
14 \\
\end{array}$ & $7.04 \mathrm{E}-13$ \\
\hline hsa-mir-4713 & 2.832803 & -0.29741 & $9.36 \mathrm{E}-06$ & $5.26 \mathrm{E}-05$ & hsa-mir-378d-1 & $\begin{array}{l}- \\
2.55416\end{array}$ & 0.146215 & $\begin{array}{l}9.49 \mathrm{E}- \\
12 \\
\end{array}$ & $1.66 \mathrm{E}-10$ \\
\hline hsa-mir-4658 & 3.809692 & -0.47128 & $1.54 \mathrm{E}-05$ & $8.33 \mathrm{E}-05$ & hsa-mir-499a & $\begin{array}{l}- \\
2.97542\end{array}$ & 2.103145 & $\begin{array}{l}2.54 \mathrm{E}- \\
11 \\
\end{array}$ & $3.80 \mathrm{E}-10$ \\
\hline hsa-mir-548f-1 & 4.284969 & 0.072804 & $1.87 \mathrm{E}-05$ & $9.87 \mathrm{E}-05$ & hsa-mir-99a & $\begin{array}{l}- \\
2.01938\end{array}$ & 9.003363 & $\begin{array}{l}5.18 \mathrm{E}- \\
11\end{array}$ & $7.24 \mathrm{E}-10$ \\
\hline
\end{tabular}

